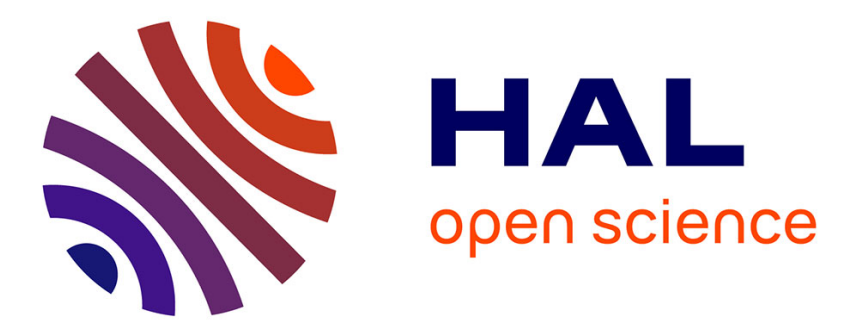

\title{
C-C bond formation strategy through ecocatalysis: Insights from structural studies and synthetic potential
}

Claire Garel, Brice-Loïc Renard, Vincent Escande, Anouk Galtayries, Peter Hesemann, Claude Grison

\section{- To cite this version:}

Claire Garel, Brice-Loïc Renard, Vincent Escande, Anouk Galtayries, Peter Hesemann, et al.. CC bond formation strategy through ecocatalysis: Insights from structural studies and synthetic potential. Applied Catalysis A: General, 2015, Nanocatalysis Science: Preparation, Characterization and Reactivity, dedicated to the scientific work of Jacques C. Vedrine, 504, pp.272-286. 10.1016/j.apcata.2015.01.021 . hal-01205866

\section{HAL Id: hal-01205866 \\ https://hal.science/hal-01205866}

Submitted on 11 Mar 2021

HAL is a multi-disciplinary open access archive for the deposit and dissemination of scientific research documents, whether they are published or not. The documents may come from teaching and research institutions in France or abroad, or from public or private research centers.
L'archive ouverte pluridisciplinaire HAL, est destinée au dépôt et à la diffusion de documents scientifiques de niveau recherche, publiés ou non, émanant des établissements d'enseignement et de recherche français ou étrangers, des laboratoires publics ou privés. 


\title{
C-C bond formation strategy through ecocatalysis: insights from structural studies and synthetic potential
}

\author{
Claire Garel $^{\mathrm{a}}$, Brice-Loïc Renard ${ }^{\mathrm{a}}$, Vincent Escande ${ }^{\mathrm{a}}$, Anouk Galtayries ${ }^{\mathrm{b}}$, Peter \\ Hesemann $^{c}$, Claude Grison ${ }^{\mathrm{a} *}$ \\ a Laboratory of Bioinspired Chemistry and Ecological Innovation - FRE 3673 - CNRS, University of Montpellier 2, \\ Stratoz - Cap Alpha, Avenue de l'Europe 34830 Clapiers, France \\ b Institut de Recherche de Chimie Paris (IRCP), CNRS - Chimie ParisTech, 11 rue Pierre et Marie Curie F - 75005 Paris, \\ France \\ c Institut Charles Gerhardt - UMR 5253, Université Montpellier 2, Place E. Bataillon, 34095 Montpellier cedex 05, \\ France \\ *Corresponding Author : claude.grison@ cnrs.fr +33467593652
}

\section{HIGHLIGHTS:}

- Efficient metal accumulation by plants via rhizofiltration

- Preparation of palladium based catalysts via thermal treatment of biomass (roots)

- Utilization of bio-sourced Pd containing materials $\left(\right.$ Eco-Pd $\left.{ }^{\mathbb{B}}\right)$ as efficient catalysts in Suzuki and Heck cross coupling reactions

- Unprecedented high catalytic activity for exclusively bio-sourced metal catalysts

\begin{abstract}
We report the elaboration of novel bio-sourced ecocatalysts for Heck and Suzuki crosscoupling reactions. Ecocatalysis is based on the recycling of metals issued from phytoremediation or rehabilitation, and an innovative chemical valorization of the subsequent biomass in the field of catalysis. Here, we describe the efficient palladium accumulation by plants (Brassica juncea, Lolium multiflorum) via rhizofiltration. Taking advantage of the remarkable ability of the selected plants to accumulate $\mathrm{Pd}$ (II) species into their roots, these latter can be directly used for the preparation of ecocatalysts, called Eco-Pd ${ }^{\mathbb{B}}$. The formed Eco-Pd ${ }^{\circledR}$ catalysts are thoroughly characterized via ICP-MS, XRD, XPS, TEM, SEM in order to elucidate the chemical composition and morphology of the formed materials. Significant differences to conventional Pdbased catalysts such as palladium (II) chloride can principally be related to a particular Lewis acid behavior of the Eco-Pd ${ }^{\circledR}$ catalysts. Finally, the obtained Eco-Pd ${ }^{\circledR}$ appear as highly active catalysts in Heck and Suzuki cross-coupling reactions necessitating considerably lower Pd quantity compared to precedently reported biosourced palladium containing catalysts.
\end{abstract}

KEYWORDS: Ecological Recycling; Rhizofiltration; Palladium; Ecocatalysis; Suzuki-Miyaura cross-coupling; HeckMizoroki cross-coupling

\section{Introduction}

Palladium is one of the most widely studied transition metals in the field of organic chemistry, partly owing to the important role of palladium complexes in catalysis. Among the most important reactions are $\pi$-allyl additions [1, 2], aromatic carbon-heteroatom bond-forming reactions [3, 4] and cross-coupling reactions [5]. Although $\mathrm{Ni}, \mathrm{Cu}$, and occasionally $\mathrm{Pt}$ have been used as catalysts for cross-coupling reactions, the large majority of cases concerns Pd. The development of new carbon-carbon bond forming reactions by palladiumcatalyzed cross-coupling has continued to increase dramatically. Industrial applications have been successfully 
developed. Numerous review articles and general references describe the high potential and interest of these reactions for organic synthesis. Finally, the fundamental and industrial importance of palladium chemistry has been recognized by the attribution of the 2010 Nobel prize in chemistry to Richard Heck, Ei-Ichi Negishi and Akira Suzuki due to their outstanding contribution to the development of Pd-catalyzed cross-coupling reactions [6-8]. Among them, Suzuki-Miyaura cross-coupling of organoboron compounds and Heck-Mizoroki alkenylation of organic electrophiles with haloarenes have settled the most general and selective reactions [912]. However, palladium recently became of high concern for the chemical industry. The Pd price lastly reached record highs due to the recent geo-economic context. The phenomenon was reinforced by an increasing demand on world markets for PGE (platinum group elements) such as Pd. Process intensification and in particular the reduction of catalyst amount and recycling become key parameters not only for ecological reasons, but also from an economical point of view. In the context of sustainable chemistry, processes that require complex ligand systems, and high quantities of organic solvent and necessitate the use of additive such as strong bases, contribute to the more critical consideration of these processes and recently initiated new approaches for transition metal catalysis, especially regarding Pd-promoted reactions $[13,14]$.

To clean up polluted soils and aquatic systems, different ecological solutions such as phytoextraction and rhizofiltration are performed in large-scale. These phytotechnologies generate plant wastes, which are valued through an innovative concept of ecological recycling. Because plants used, the metallophytes, are able to hyperaccumulate primary or strategic metals as $\mathrm{Zn}^{2+}, \mathrm{Ni}^{2+}, \mathrm{Mn}^{2+}, \mathrm{Cu}^{2+}, \mathrm{Co}^{2+}$ et $\mathrm{Pd}^{2+}$, they can be directly used as reagents and catalysts in organic fine chemical reactions.

This original approach brings the first perspective of enhancing the unique biomass and establishes a new field of Green Chemistry. Our group recently introduced the concept of Ecocatalysis as a new approach for sustainable catalysis [15-18].

Thus, the concept of Ecocatalysis is based on two principles: first the recycling of (transition) metals issued from the phytoremediation, rehabilitation, or full-fledged ecological restoration of contaminated soils and aquatic systems [19, 20]; secondly, an innovative chemical recovery of subsequent biomass [21, 22]. Recycling and reuse of metallophytes constitute the starting point of an original and highly promising concept in chemistry, named "ecocatalysis" [23, 24]. The first results have shown that ecocatalysts could present performances and selectivities which are significantly higher than those observed with classical homogeneous and heterogeneous catalysts [25-27]. They can be used as catalysts or reagents in the synthesis of molecules with high added value in fine and industrial chemistry (cosmetics, drugs and oligomers with biological interests, highly functionalized aromatic heterocycles, and biopesticides) [28-30]. As an example, we reported metallic species phytoextracted from Mn hyperaccumulators which allow the development of substitutive reagents to oxidants forbidden by REACH [31]. This approach represents a very efficient alternative to catalysts derived from metallurgy, with a three dimension domain of chemistry/ecology/environment.

In this article, we describe the ecological recycling of effluents rich in Pd. The developed ecological solution is the rhizofiltration. Because the selected plants are able to accumulate $\mathrm{Pd}^{2+}$ into their roots, they can be directly used as ecocatalysts, called Eco-Pd ${ }^{\circledR}$. The preparation, characterization and reactivity of these ecocatalysts in Suzuki-Miyaura and Heck-Mizoroki coupling reactions are described.

\section{2 - Experimental}

\subsection{Rhizofiltration}

Conditions of rhizofiltration: Brassica juncea and Lolium multiflorum.

\section{Germination}


Seeds were first transferred in Fleximix Root Riot Organic Starter Cubes ${ }^{\mathcal{O}}, 42.3 \%(\mathrm{SD}=3.03)$ of seeds were germinated after 3 days. This mixture of coco coir, peat and bark which has good aeration and drainage properties was then always used for further germinations of Brassica juncea or Lolium multiflorum. Cubes were placed inside baskets within clay pebbles. A comparative study with rock wool was carried out. They were exposed under neon light which have 11000 lumens during 30 days, after what seedlings were subjected to waste water solution.

Conditions of growing and accumulation

After 30 days seedlings of Brassica juncea and Lolium multiflorum baskets were exposed to concentrations of $40 \mathrm{mg} / \mathrm{L}$ of $\mathrm{Pd}\left(\mathrm{NH}_{3}\right)_{4}\left(\mathrm{NO}_{3}\right)_{2}$. The $\mathrm{pH}$ of the solution was a critical parameter affecting Pd uptake. According to Harris et al. [32], the $\mathrm{pH}$ was kept constant at 3 by pipetting from an appropriate solution of $\mathrm{HNO}_{3}$ during the experiments. The environmental factors: temperature $\left(20-27{ }^{\circ} \mathrm{C}\right.$ ), light intensity (mercury lamp UV, 37000 lumens), period of light ( $16 \mathrm{~h}$ per day), and relative humidity were kept unchanged during the experiments. The plants were fed with synthetic wastewater (called "water lily dream") containing $1 \% \mathrm{~K}_{2} \mathrm{O}, 0.14 \% \mathrm{Mo}, 0.0028 \%$ $\mathrm{Zn}, 0.0027 \% \mathrm{Cu}, 0.0004 \% \mathrm{Li}$.

\section{Crops}

Brassica juncea and Lolium multiflorum were collected and separated into roots and aerial parts. Plant tissues were washed and rinsed with deionized water to remove any metallic particles attached to the plant surfaces.

\section{Evaluation of rhizofiltration parameters}

Biomass measuring:

After 1 week and 8 weeks, the plants were retrieved and separated in root and shoot compartments using a scissor.

The live plant biomass compartments were weighed before and after they were dried at $80{ }^{\circ} \mathrm{C}$ for $48 \mathrm{~h}$ for analyzing the mineral composition.

$\mathrm{BCF}$ (bioconcentration factor):

The $\mathrm{BCF}$ was calculated as the ratio of a given element concentration in the plant tissues $(\mathrm{P}, \mathrm{mg} / \mathrm{Kg}$ dry weight) at harvest to the concentration of the element in the effluent (E, $\mathrm{mg} / \mathrm{L})$ according to Eq.(1)

$$
\mathrm{BCF}=\mathrm{P} / \mathrm{E}
$$

TF (translocation factor):

TF was calculated by dividing the Pd concentration in root tissues $\left(A_{r}, \mathrm{mg} / \mathrm{Kg}\right.$ dry weight) by the concentration

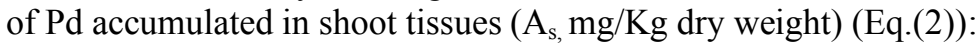

$\mathrm{TF}=\left(\mathrm{A}_{\mathrm{s}} / \mathrm{A}_{\mathrm{r}}\right)$

The determination of metals concentration in roots, shoots and aqueous effluents were determined by ICP-MS (inductively coupled plasma mass spectrometry), (see 2.3.1. Chemical element analysis).

\subsection{Preparation of Eco-Pd catalysts}

Eco-Pd ${ }^{\circledR}$ catalysts were prepared from harvested plants' roots. Roots were first dried into an oven at $80{ }^{\circ} \mathrm{C}$, then thermally treated in an oven either under air flow $\left(\mathrm{Eco}^{\circ} \mathrm{Pd}_{1}{ }^{\circledR}\right)$ or under argon flow $\left(\mathrm{Eco}^{\mathrm{P}} \mathrm{Pd}_{2}{ }^{\circledR}\right)$. Under air flow, the following temperature program was used: $20-350{ }^{\circ} \mathrm{C}$ in one hour, $350-550{ }^{\circ} \mathrm{C}$ in one hour, then 4 hours at $550{ }^{\circ} \mathrm{C}$. Under argon flow, the following program was used: $20-350{ }^{\circ} \mathrm{C}$ in one hour, two hours isothermal at $350{ }^{\circ} \mathrm{C}$, then $350-550{ }^{\circ} \mathrm{C}$ in one hour, and two hours at $550{ }^{\circ} \mathrm{C}$.

Part of Eco-Pd ${ }_{1}^{\circledR}$ and Eco-Pd ${ }_{2}^{\circledR}$ was used to prepare respectively Eco-Pd ${ }_{3}^{\circledR}$ and Eco-Pd ${ }^{\circledR}$ by a chemical treatment. The typical procedure used was as follow: around $50 \mathrm{mg}$ of Eco- $\mathrm{Pd}_{1}{ }^{\circledR}$ or Eco-Pd ${ }_{2}^{\circledR}$ were suspended in concentrated hydrochloric acid. The solutions were stirred under reflux at $60{ }^{\circ} \mathrm{C}$ during $24 \mathrm{~h}$, under air for Eco$\mathrm{Pd}_{3}{ }^{\circledR}$ and under inert atmosphere for Eco-Pd ${ }_{4}{ }^{\circledR}$. Solutions were heterogeneous, brown for Eco- $\mathrm{Pd}_{3}{ }^{\circledR}$ and black for Eco-Pd ${ }^{\circledR}$. Then hydrochloric acid was evaporated under vacuum. Eco-Pd ${ }_{3}{ }^{\circledR}$ and Eco-Pd ${ }_{4}{ }^{\circledR}$ were obtained under the form respectively of brown and black powder. All Eco-Pd ${ }^{\circledR}$ catalysts were stored under vacuum in a desiccator. 


\subsection{Characterization of Eco-Pd $d^{\circledR}$ catalysts}

\subsubsection{Chemical element analysis}

ICP-MS was used to confirm the composition of the various ecocatalysts obtained. ICP-MS analyses were performed using the metal analysis of total dissolved solutes in water. The samples were first digested in a mixture of hydrochloric acid $(37 \%)(8 \mathrm{~mL})$ and nitric acid $(65 \%)(2 \mathrm{~mL})$ using a microwave-assisted digestion (Mileston ETHOS Tauch) with the following program: $20-90{ }^{\circ} \mathrm{C}$ in $7 \mathrm{~min}, 90-170{ }^{\circ} \mathrm{C}$ in $5 \mathrm{~min}, 170-210{ }^{\circ} \mathrm{C}$ in 3 $\mathrm{min}$, and then $20 \mathrm{~min}$ isothermal at $210^{\circ} \mathrm{C}$. Samples were then diluted to $0.1 \mathrm{mg} . \mathrm{L}^{-1}$ in nitric acid $2.5 \%$. Three blanks were recorded for each step of the digestion and dilution procedure on a HR-ICP-MS Thermo Scientific Element XR. All analysis results were performed in triplicate.

\subsubsection{XPS analysis}

XPS analyses were performed with an ESCALAB 250 spectrometer (Thermo Electron Corporation), using a monochromatized focused Al Ka X-ray source $(1486.6 \mathrm{eV})$. The calibration of the spectrometer was done with $\mathrm{Cu} 2 \mathrm{p}_{3 / 2}(932.8 \mathrm{eV}), \mathrm{Au} 4 \mathrm{f}_{7 / 2}(84.0 \mathrm{eV})$ and $\mathrm{Ag} 3 \mathrm{~d}_{5 / 2}(368.6 \mathrm{eV})$. Base pressure during analysis was about $10^{-7}$ $\mathrm{Pa}$. The analysed area had a diameter of about $500 \mu \mathrm{m}$. In addition to the survey spectrum (pass energy of 100 $\mathrm{eV}$ ), the following core levels were systematically recorded at high resolution (pass energy of $20 \mathrm{eV}$ ): $\mathrm{C} 1 \mathrm{~s}, \mathrm{O}$ 1s, N 1s, Na 1s, Al 2p, Si 2p, Cl 2p, Ca 2p, S 2p, Fe 2p and Pd 3d. For all analyses the take-off angle was $90^{\circ}$. The powder was deposited on a double sided tape and a $2 \mathrm{eV}$ flood gun was used during all time of the analysis of Eco-Pd ${ }_{1}{ }^{\circledR}$ and Eco-Pd ${ }_{3}{ }^{\circledR}$, which were not conductive. The data processing (peak fitting) was performed with the CasaXPS version 2.3.16, using a Shirley type background and Gaussian/Lorentzian peak shapes. The metallic contribution in the Pd $3 \mathrm{~d}$ core level was fitted with a Doniach-Sunjic line when it was detected. To take into account the surface charge effects, the binding energies were corrected by setting the hydrocarbon peak in the $\mathrm{C} 1 \mathrm{~s}$ core level at $285.0 \mathrm{eV}$.

\subsubsection{X-ray diffraction}

X-ray diffraction (XRD) data measurements on the samples dried at $110{ }^{\circ} \mathrm{C}$ for 2 hours were performed by using a BRUKER diffractometer (D8 advance, with a $\mathrm{Cu} \mathrm{K \alpha}$ radiation $\lambda=1.54086 \AA$ ) equipped with a Lynxeyes detector.

2.3.3. SEM (scanning electron microscope) and TEM (transmision electron microscope) images, and EDS (energy dispersive X-ray spectroscopy) analyses

SEM images were obtained using a Hitachi S-4800 Scanning Electron Microscope. Eco-Pd ${ }^{\circledR}$ catalysts were mounted on a support holder thanks to a double-sided conducting adhesive tape. Images were obtained using back-scattered electrons.

TEM images were taken using a Jeol 1200-EX2 Transmission Electron Microscope at accelerating voltage of $100 \mathrm{kV}$. In each case, ecocatalysts were ground into a thin powder, and put in suspension in hexane. Each suspension of ecocatalyst was dropped off on a grid CF $300-\mathrm{Cu}$ (carbon film on 300 Mesh copper grids).

EDS analysis with energy resolution $133 \mathrm{eV}$ in scanning mode was performed using a Jeol JEM-2200FS Field Emission Electron Microscope at accelerating voltage of $200 \mathrm{kV}$. In each case, ecocatalysts were ground into a thin powder, and suspended in hexane. Each suspension of ecocatalyst was dropped off on a grid $\mathrm{CF} 300-\mathrm{Cu}$ (carbon film on 300 Mesh copper grids).

\subsubsection{Acidity characterization}

Pyridine-FTIR (Fourier transform infrared spectroscopy):

FTIR measurements were carried out using pyridine as a probe. A PerkinElmer Spectrum100 FT-IR spectrometer was used for recording the spectra. Excess pyridine was adsorbed, then the samples were 
degassed for $15 \mathrm{~min}$ at $25^{\circ} \mathrm{C}\left(10^{-3} \mathrm{~Pa}\right)$ and a first spectrum was recorded. The samples were then degassed for $25 \mathrm{~min}$ at $150^{\circ} \mathrm{C}\left(10^{-3} \mathrm{~Pa}\right)$ to eliminate the physisorbed pyridine and a second spectrum was recorded.

Rearrangement of 2-bromopropiophenone ethylene acetal:

With Eco-P $d_{3}{ }^{\circledR}$ and $E c o-P d_{4}{ }^{\circledR}$ : A solution of 2-bromopropiophenone ethylene acetal $(15.15 \mathrm{mg}, 0.0589 \mathrm{mmol}, 1$ equiv.) in 1,2-dichlorobenzene $(658 \mu \mathrm{L})$ was poured onto catalyst (mass corresponding to $0.00248 \mathrm{mmol}$ of $\mathrm{Pd}$, 0.04 equiv.), with water $\left(1.06 \mu \mathrm{L}, 0.0589 \mathrm{mmol}, 1\right.$ equiv.). The resulting suspension was stirred at $180{ }^{\circ} \mathrm{C}$ for $20 \mathrm{~h}$. The mixture reaction was analyzed by GC-MS. Gas chromatography and mass spectrometry analyses were performed using a Shimadzu QP2010SE apparatus, equipped with a $30 \mathrm{~m}$ x $0.25 \mathrm{~mm}$ x $0.25 \mu \mathrm{m}$ ZB-5MSi Guardian column (Phenomenex ${ }^{\circledR}$ ) with hydrogen as carrier gas. The following temperature program was used: $4 \mathrm{~min}$ isothermal at $80^{\circ} \mathrm{C}$, then increasing from $80^{\circ} \mathrm{C}$ to $270{ }^{\circ} \mathrm{C}$ at $20^{\circ} \mathrm{C} / \mathrm{min}$. Mass spectra were recorded in electron impact (EI) mode at $70 \mathrm{~V}$ and identified by comparison with data of the NIST 11 software library and by comparison of the retention time of the standard compounds.

With $\mathrm{PdCl}_{2}$ : A solution of 2-bromopropiophenone ethylene acetal (75.76 mg, $0.2947 \mathrm{mmol}, 1$ equiv.) in 1,2dichlorobenzene $(3.29 \mathrm{~mL}$ ) was poured onto catalyst (mass corresponding to $0.01238 \mathrm{mmol}$ of Pd, 0.04 equiv.), with water $\left(5.31 \mu \mathrm{L}, 0.2947 \mathrm{mmol} 1\right.$ equiv.). The resulting suspension was stirred at $180{ }^{\circ} \mathrm{C}$ for $20 \mathrm{~h}$. The mixture reaction was analyzed by GC-MS as described above.

\subsection{Analysis of reaction products}

NMR spectra were recorded on a Brüker Avance 300 spectrometer at room temperature, ${ }^{1} \mathrm{H}$ frequency is at 300 $\mathrm{MHz},{ }^{13} \mathrm{C}$ frequency is at $75 \mathrm{MHz}$. IR spectra were recorded on a PerkinElmer Spectrum $100 \mathrm{FT}-\mathrm{IR}$ spectrometer, in ATR mode. GC-MS analyses were performed on a Shimadzu QP2010SE apparatus, equipped with a $30 \mathrm{~m}$ x $0.25 \mathrm{~mm} \times 0.25 \mu \mathrm{m}$ ZB-5MSi Guardian column (Phenomenex ${ }^{\circledR}$ ) with hydrogen as carrier gas.

\subsection{Representative procedure for Suzuki-Miyaura coupling reactions}

In a typical procedure, to $280 \mathrm{mg}$ of $\mathrm{K}_{3} \mathrm{PO}_{4}(1.3 \mathrm{mmol}, 3$ equiv.) were added under inert atmosphere $63 \mathrm{mg}$ of phenylboronic acid (0.52 mmol, 1.2 equiv.), aryl halide $\left(0.43 \mathrm{mmol}, 1\right.$ equiv.), $E c o-\mathrm{Pd}_{3}{ }^{\circledR}$ and $2 \mathrm{~mL}$ of anhydrous toluene. After stirring $15 \mathrm{~h}$ at $100{ }^{\circ} \mathrm{C}$, yield of cross-coupling product were estimated by GC-MS analysis.

\subsection{Representative procedure for Heck-Mizoroki coupling reactions}

In a typical procedure, Eco-Pd ${ }_{3}^{\circledR}$ catalyst (amount corresponding to $0.12 \mathrm{~mol} \%$ of Pd) was poured in a sealed tube containing $2 \mathrm{~mL}$ of a mixture of $N$-methyl-2-pyrrolidone/water $2: 1$, then were added successively $\mathrm{n}$ tetrabutylammonium bromide ( $0.06 \mathrm{mmol}, 0.6$ equiv.), anhydrous sodium acetate $(0.13 \mathrm{mmol}, 1.3$ equiv.), aryl halide $\left(0.10\right.$ mmol, 1 equiv.) and alkene ( 0.14 mmol, 1.4 equiv.). After stirring $24 \mathrm{~h}$ at $140^{\circ} \mathrm{C}$ under $\mathrm{N}_{2}$ atmosphere, conversion and selectivity were estimated by GC-MS analysis.

\section{3 - Results and discussion}

\subsection{Rhizofiltration}

Lolium multiflorum and Brassica juncea were selected as model plants because both have previously been shown to accumulate and concentrate Pt group elements (PGE). Lolium multiflorum is a European grass easy to cultivate [33], Brassica juncea is a widespread and dominant brassica in rhizofiltration [32], because this species is more agronomically performant than Arabidobsis thaliana or Sinapsis alba.

\section{Plant growth under rhizofiltration}

Before studying the rhizofiltration by plants, the choice of the most adapted species for the ecocatalysis required the knowledge of germination $\%$, plant biomass growth and the biomass measuring (table 1 ). The plant growth influences the amount of roots biomass available for the removal of Pd from effluent, and also affects the available amount of Eco-Pd ${ }^{\circledR}$. 
In the preliminary experiments, germination $\%$ and plant growth under different systems were carried out with high Pd concentration $\left(40 \mathrm{mg} / \mathrm{L}\right.$ of $\left.\mathrm{Pd}\left(\mathrm{NH}_{3}\right)_{4}\left(\mathrm{NO}_{3}\right)_{2}\right)$. The Brassica juncea germination \% is lower than the one observed with Lolium multiflorum. Though both plants tolerated this concentration well, period of exposure of Brassica juncea was limited by a flowering after 9 weeks. It is clear that biomass measuring with Lolium multiflorum gave better results in terms of rhizofiltration and the ease of ecocatalysts preparation (table 1). Indeed, as shown in table 1, after 9 weeks and with Fleximix Root Riot Organic Starter Cubes, root biomass is 55 times higher than with $B$. juncea.

Table 1. Germination \% and biomass measuring (mg/plant) for B. juncea and L. multiflorum grown on different substrates

\begin{tabular}{|c|c|c|c|c|c|}
\hline Species & Substrate & $\begin{array}{c}\text { Germination } \\
\%\end{array}$ & $\begin{array}{c}\text { Growth } \\
\text { period } \\
\text { (weeks) }\end{array}$ & $\begin{array}{c}\text { Root biomass } \\
\text { (mg/plant) }\end{array}$ & $\begin{array}{c}\text { Shoot } \\
\text { biomass } \\
\text { (mg/plant) }\end{array}$ \\
\hline \multirow{2}{*}{$\begin{array}{l}\text { Brassica } \\
\text { juncea }\end{array}$} & Rock woll & 66.8 & 1 & 4.04 & 17.2 \\
\hline & $\begin{array}{l}\text { Fleximix Root Riot Organic } \\
\text { Starter Cubes }{ }^{\mathrm{a}}\end{array}$ & 78.5 & 9 & 8.49 & 299 \\
\hline \multirow{2}{*}{$\begin{array}{l}\text { Lolium } \\
\text { multiflorum }\end{array}$} & Rock wool & 92.8 & $\begin{array}{l}1 \\
9\end{array}$ & $\begin{array}{l}16.9 \\
1170\end{array}$ & $\begin{array}{l}17.4 \\
762\end{array}$ \\
\hline & $\begin{array}{c}\text { Fleximix Root Riot Organic } \\
\text { Starter Cubes }{ }^{\mathrm{a}, \mathrm{b}}\end{array}$ & 84.6 & 9 & 466 & 223 \\
\hline
\end{tabular}

${ }^{\mathrm{a}}$ Cubes were placed inside baskets within clay pebbles

${ }^{\mathrm{b}}$ In hydroponics without clay pebbles, root biomass is $127 \pm 22 \mathrm{mg} / \mathrm{plant}$

Plant analysis: determination of metal concentration in roots and leaves

Palladium concentration in roots and leaves was measured by ICP-MS analysis for B. juncea and L. multiflorum, grown on Fleximix Root Riot Organic Starter Cubes, with or without clay pebbles (table 2).

Table 2. Palladium concentration in roots and leaves (wt $\%, \pm$ standard deviation), and BCF and TF calculation

\begin{tabular}{|c|c|c|c|c|c|c|}
\hline Plant & Substrate $^{a}$ & $\begin{array}{c}\text { Roots } \\
(w t \% \pm \text { SD })\end{array}$ & $\begin{array}{c}\text { BCF } \\
\text { (in roots) }\end{array}$ & $\begin{array}{c}\text { Leaves } \\
(w t \% \pm S D)\end{array}$ & $\begin{array}{c}\text { BCF } \\
\text { (in leaves) }\end{array}$ & TF \\
\hline B. juncea & Clay pebbles & $0.68 \pm 0.0018$ & 475 & $0.0020 \pm 0.000013$ & 1.4 & 340 \\
\hline L. multiflorum & Clay pebbles & $0.43 \pm 0.0034$ & 302 & $0.0011 \pm 0.000012$ & 0.8 & 393 \\
\hline L. multiflorum & $\begin{array}{c}\text { Without clay } \\
\text { pebbles }\end{array}$ & $2.58 \pm 0.0596$ & 1801 & $0.0075 \pm 0.0005$ & 5.2 & 343 \\
\hline
\end{tabular}

With clay pebbles, concentration of palladium in roots is a bit higher in B. juncea than in L. mutiflorum. However, accumulation of palladium by L. multiflorum without clay pebbles shows promising results with a concentration of palladium in roots 6 times higher than the concentration obtained with clay pebbles. One possible explanation for such different results might be that the major part of palladium is adsorbed on clay pebbles which decreases the amount of palladium available for plants' roots. Lesniewska et al. have obtained $1.63 \mathrm{wt} \%$ of palladium in L. multiflorum roots with $21.6 \mathrm{mg} / \mathrm{L}$ palladium in effluent (mixed with platinum and rhodium) after 8 days [34]. This value, even smaller, is coherent with our result without clay pebbles.

BCF and TF factors were calculated for cultures with and without clay pebbles. Results with clay pebbles show that only a small part of palladium is translocated from roots to leaves. Translocation is lower in L. multiflorum than in B. juncea, which is an asset to prepare ecocatalysts from plants' roots. Without clay pebbles, translocation remains low and the concentration of palladium in L. multiflorum leaves is slightly higher than the one obtained by Lesniewska et al. [34]. 
Germination rates and roots biomass of L. multiflorum are by far higher than those of $B$. juncea, which are important criteria to produce ecocatalysts from plants' roots. Although $B$. juncea accumulates slightly more palladium than L. multiflorum, translocation from roots to leaves is lower in L. multiflorum, which definitely makes this plant the best option for rhizofiltration and to produce Eco-Pd ${ }^{\circledR}$.

\section{Effluent analysis}

L. multiflorum appears to be the best solution to produce Eco-Pd ${ }^{\circledR}$, its ability to remove palladium from a contaminated effluent was important. Maintaining constant the volume of solution into the hydroponics reservoir (without clay pebbles), palladium concentration was followed by ICP-MS. After five days, concentration of palladium in the effluent decreased from $14 \mathrm{mg} / \mathrm{L}$ to $3 \mathrm{mg} / \mathrm{L}$. Between the fifth and the fourteenth day of accumulation, palladium concentration did not change significantly. Lesniewska et al. reported that for accumulation period longer than five days, the uptake rate tends to saturate, which is in accordance with our results [34]. It clearly shows the ability of L. multiflorum to decontaminate effluents. (Without stirring in the hydroponic reservoir, we observed that palladium salts can precipitate on the walls of the reservoir)

\subsection{Preparation and characterization of the Eco-Pd}

\section{Preparation of Eco-Pd $d^{\circledR}$}

Eco-Pd ${ }^{\circledR}$ were produced from L. multiflorum roots, following the previously described procedure. Eco-Pd ${ }_{1}^{\circledR}$ and Eco- $\mathrm{Pd}_{2}{ }^{\circledR}$ are ashes produced by thermal treatment of roots under air flow and under argon flow respectively. Eco-Pd ${ }_{3}^{\circledR}$ and Eco-Pd ${ }_{4}{ }^{\circledR}$ were produced by chemical treatment with hydrochloric acid of Eco-Pd ${ }_{1}{ }^{\circledR}$ and Eco-Pd ${ }^{\circledR}$ respectively. This latter step enables metal chloride formation inside of the ecocatalysts.

$E c o-P d^{\circledR}$ are stable and can be stored at room temperature under nitrogen for long period.

\section{ICP-MS analyses of Eco-Pd $d^{\circledR}$}

Table 3 shows mineral composition of Eco-Pd ${ }^{\circledR}$ catalysts obtained with L. multiflorum, with or without clay pebbles. Some results obtained for $B$. juncea are also indicated for comparison. Concentrations are higher in Eco-Pd ${ }_{1}^{\circledR}$ and Eco-Pd ${ }_{3}{ }^{\circledR}$ than in Eco-Pd ${ }_{2}{ }^{\circledR}$ and Eco-Pd ${ }_{4}{ }^{\circledR}$ respectively, which is due to the applied thermal treatment. Indeed, calcination under air flow leads to a higher loss of organic matter (90 to $95 \%$ of mass loss) whereas, calcination under argon flow preserves part of carbon content in the ashes (70 to $75 \%$ of mass loss). Preliminary results obtained for L. multiflorum without clay pebbles are promising: concentrations of palladium in $\mathrm{Eco}-\mathrm{Pd}_{1}{ }^{\circledR}, \mathrm{Eco}-\mathrm{Pd}_{2}{ }^{\circledR}$ and $\mathrm{Eco}-\mathrm{Pd}_{3}{ }^{\circledR}$ are more than 3 times higher than those obtained with clay pebbles. However, this paper only describes ecocatalysts made with L. multiflorum grown on clay pebbles. Results of catalysts obtained without clay pebbles will be reported in due time.

Mineral composition of Eco-Pd ${ }^{\mathbb{B}}$ made from $B$. juncea is not really different from mineral composition of Eco$\mathrm{Pd}^{\circledR}$ from L. multiflorum, except for calcium. Palladium concentration is almost the same, even a bit higher in Eco-Pd ${ }^{\circledR}$ from L. multiflorum than in those from B. juncea. These results indicate that the choice of the accumulating plant for rhizofiltration does only slightly impact the mineral composition of produced Eco-Pd ${ }^{\circledR}$.

Table 3. Mineral composition of Eco-Pd ${ }^{\circledR}$ catalysts $(w t \% \pm \mathrm{SD})$ established by ICP-MS analysis.

\begin{tabular}{|c|c|c|c|c|c|c|c|c|c|}
\hline \multirow[t]{2}{*}{ Ecocatalysts } & \multirow[t]{2}{*}{ Plant } & \multicolumn{8}{|c|}{ Mineral composition $(w t \% \pm$ SD) } \\
\hline & & $\mathbf{N a}$ & Mg & Al & $\mathbf{K}$ & Ca & $\mathrm{Fe}$ & $\mathbf{Z n}$ & Pd \\
\hline \multirow[t]{2}{*}{ Eco-Pd $_{1}{ }^{\circledR}$} & L. multiflorum ${ }^{a}$ & $\begin{array}{c}5.85 \\
( \pm 0.0341)\end{array}$ & $\begin{array}{c}1.18 \\
( \pm 0.0074)\end{array}$ & $\begin{array}{c}2.18 \\
( \pm 0.0083)\end{array}$ & $\begin{array}{c}3.89 \\
( \pm 0.0444)\end{array}$ & $\begin{array}{c}8.37 \\
( \pm 0.0878)\end{array}$ & $\begin{array}{c}2.70 \\
( \pm 0.0049)\end{array}$ & $\begin{array}{c}0.18 \\
( \pm 0.0001)\end{array}$ & $\begin{array}{c}7.81 \\
( \pm 0.0439)\end{array}$ \\
\hline & L. multiflorum ${ }^{b}$ & $\begin{array}{c}5,34 \\
( \pm 0.019)\end{array}$ & $0,82( \pm 0.0079)$ & - & $\begin{array}{c}4,21 \\
( \pm 0.061)\end{array}$ & $\begin{array}{c}7,72 \\
( \pm 0.21)\end{array}$ & $\begin{array}{c}3,20 \\
( \pm 0.032)\end{array}$ & $\begin{array}{c}2,13 \\
( \pm 0.033)\end{array}$ & $\begin{array}{c}25,29 \\
( \pm 0.40)\end{array}$ \\
\hline \multirow[t]{3}{*}{ Eco-Pd ${ }^{\circledR}$} & B. juncea ${ }^{a}$ & $3.61( \pm 0.0091)$ & $\begin{array}{c}0.58 \\
( \pm 0.0068)\end{array}$ & $\begin{array}{c}0.36 \\
( \pm 0.0064)\end{array}$ & $\begin{array}{c}0.76 \\
( \pm 0.0056)\end{array}$ & $\begin{array}{c}21.34 \\
( \pm 0.21)\end{array}$ & $\begin{array}{c}0.30 \\
( \pm 0.0023)\end{array}$ & $\begin{array}{c}0.15 \\
( \pm 0.0019)\end{array}$ & $\begin{array}{c}1.36 \\
( \pm 0.0077)\end{array}$ \\
\hline & L. multiflorum ${ }^{a}$ & $\begin{array}{c}3.46 \\
( \pm 0.0042)\end{array}$ & $\begin{array}{c}0.43 \\
( \pm 0.0033)\end{array}$ & $\begin{array}{c}0.43 \\
( \pm 0.0055)\end{array}$ & $\begin{array}{c}1.01 \\
( \pm 0.0042)\end{array}$ & $\begin{array}{c}3.30 \\
( \pm 0.049)\end{array}$ & $\begin{array}{c}0.61 \\
( \pm 0.0042)\end{array}$ & $\begin{array}{c}0.13 \\
( \pm 0.0009)\end{array}$ & $\begin{array}{c}1.53 \\
( \pm 0.0045)\end{array}$ \\
\hline & L. multiflorum ${ }^{\mathrm{b}}$ & $\begin{array}{c}3.15 \\
( \pm 0.077)\end{array}$ & $\begin{array}{c}0.28 \\
( \pm 0.0058)\end{array}$ & & $\begin{array}{c}1.47 \\
( \pm 0.050)\end{array}$ & $\begin{array}{c}4.57 \\
( \pm 0.24)\end{array}$ & $\begin{array}{c}0.55 \\
( \pm 0.014)\end{array}$ & $\begin{array}{c}2.68 \\
( \pm 0.029)\end{array}$ & $\begin{array}{c}4.65 \\
( \pm 0.080)\end{array}$ \\
\hline
\end{tabular}




\begin{tabular}{|c|c|c|c|c|c|c|c|c|c|}
\hline Eco-Pd ${ }_{3}^{\circledR}$ & L. multiflorum ${ }^{a}$ & $\begin{array}{c}6.34 \\
( \pm 0.099)\end{array}$ & $\begin{array}{c}1.06 \\
( \pm 0.0029)\end{array}$ & $\begin{array}{c}1.90 \\
( \pm 0.0085)\end{array}$ & $\begin{array}{c}3.77 \\
( \pm 0.038)\end{array}$ & $\begin{array}{c}7.57 \\
( \pm 0.068)\end{array}$ & $\begin{array}{c}2.17 \\
( \pm 0.0092)\end{array}$ & $\begin{array}{c}0.24 \\
( \pm 0.0024)\end{array}$ & $\begin{array}{c}6.59 \\
( \pm 0.0074)\end{array}$ \\
\hline & L. multiflorum ${ }^{\mathrm{b}}$ & $\begin{array}{c}5.35 \\
( \pm 0.11)\end{array}$ & $\begin{array}{c}0.74 \\
( \pm 0.016)\end{array}$ & & $\begin{array}{c}3.80 \\
( \pm 0.067)\end{array}$ & $\begin{array}{c}8.35 \\
( \pm 0.18)\end{array}$ & $\begin{array}{c}2.03 \\
( \pm 0.052)\end{array}$ & $\begin{array}{c}4.83 \\
( \pm 0.042)\end{array}$ & $\begin{array}{c}22.36 \\
( \pm 0.57)\end{array}$ \\
\hline \multirow[t]{2}{*}{ Eco-Pd ${ }_{4}^{\circledR}$} & B. juncea $^{a}$ & $\begin{aligned} & 3.90 \\
( \pm & 0.0063)\end{aligned}$ & $\begin{array}{c}0.54 \\
( \pm 0.0019)\end{array}$ & $\begin{array}{c}0.33 \\
( \pm 0.0037)\end{array}$ & $\begin{array}{c}1.29 \\
( \pm 0.0051)\end{array}$ & $\begin{array}{c}14.09 \\
( \pm 0.076)\end{array}$ & $\begin{array}{c}0.23 \\
( \pm 0.0005)\end{array}$ & $\begin{array}{c}0.06 \\
( \pm 0.00024)\end{array}$ & $\begin{array}{c}1.14 \\
( \pm 0.0056)\end{array}$ \\
\hline & L. multiflorum ${ }^{a}$ & $\begin{array}{c}3.71 \\
( \pm 0.012)\end{array}$ & $\begin{array}{c}0.46 \\
( \pm 0.0041)\end{array}$ & $\begin{array}{c}0.45 \\
( \pm 0.0033)\end{array}$ & $\begin{array}{c}0.89 \\
( \pm 0.0059)\end{array}$ & $\begin{array}{c}3.32 \\
( \pm 0.040)\end{array}$ & $\begin{array}{c}0.63 \\
( \pm 0.0053)\end{array}$ & $\begin{array}{c}0.08 \\
( \pm 0.0011)\end{array}$ & $\begin{array}{c}1.36 \\
( \pm 0.0025)\end{array}$ \\
\hline
\end{tabular}

${ }^{\mathrm{a}}$ Grown on Fleximix Root Riot Organic Starter Cubes in baskets with clay pebbles

${ }^{\mathrm{b}}$ Grown on Fleximix Root Riot Organic Starter Cubes without clay pebbles

\section{Characterization of Lewis acidity of Eco-Pd $d^{\mathbb{R}}$}

We studied Lewis acid properties of Eco-Pd ${ }_{3}{ }^{\circledR}$ and Eco- $\mathrm{Pd}_{4}{ }^{\circledR}$, obtained after hydrochloric acid treatment. First, it is necessary to describe and compare Lewis acidy of Eco- $\mathrm{Pd}^{\circledR}$ and commercial $\mathrm{PdCl}_{2}$ for their applications in organic synthesis. Lewis acids are usually characterized by their strength and their hardness (or softness) according to the Principle of Hard and Soft Acids and Bases (HSAB principle) described by Pearson [35, 36].

Two methods were used to assess Lewis acid properties of Eco- $\mathrm{Pd}^{\circledR}$ and commercial $\mathrm{PdCl}_{2}$. The first one is based on the IR spectroscopic characterization of adsorbed pyridine on the catalysts, and indicates the strength of the Lewis acidity. The second method, introduced by Corma et al. consists in studying rearrangement reactions of a cyclic acetal, to evaluate the hardness of the Lewis acidity [37].

\section{Pyridine adsorption}

Pyridine is widely used as a probe for the determination of Lewis acidity and Brønsted acidity of solid acids, by monitoring absorption bands in the range of $1400-1650 \mathrm{~cm}^{-1}[38,39]$. Only the Lewis acidity is considered here. Infrared spectra of pyridine adsorbed on Eco- $\mathrm{Pd}^{\circledR}$ and commercial palladium chloride were recorded at $25{ }^{\circ} \mathrm{C}$ and $150{ }^{\circ} \mathrm{C}$ in order to distinguish physisorbed pyridine and coordinated pyridine to Lewis acid sites (Table 4). Lewis acidity of Eco- $\mathrm{Pd}_{3}{ }^{\circledR}$ and $\mathrm{Eco}-\mathrm{Pd}_{4}{ }^{\circledR}$ have been studied by this method.

Table 4. Frequencies of the absorption bands observed on the IR spectra of adsorbed pyridine on catalysts after brief outgassing at $150^{\circ} \mathrm{C}$. Only absorption bands characteristic of Pyridine bonded to Lewis acid sites are reported.

\begin{tabular}{cccc}
\hline & $\begin{array}{c}\mathbf{P d C l}_{\mathbf{2}} \\
\left(\mathbf{v}_{\mathbf{C C N}}, \mathbf{c m}^{-\mathbf{1}}\right)\end{array}$ & $\begin{array}{c}\mathbf{E c o - P d}{ }_{3}{ }^{\circledR} \\
\left(\mathbf{v}_{\mathbf{C C N}}, \mathbf{c m}^{-1}\right)\end{array}$ & $\begin{array}{c}\mathbf{E c o -}-\mathbf{P d}_{\mathbf{4}}{ }^{\circledR} \\
\left(\mathbf{v}_{\mathbf{C C N}}, \mathbf{c m}^{-1}\right)\end{array}$ \\
\hline $\begin{array}{c}\text { Lewis acid site-Pyridine bond } \\
\mathbf{v}\left(\mathbf{1 6 0 0 - 1 6 3 3} \mathbf{~ m}^{-1}\right)\end{array}$ & 1604 & $1605,(1636)$ & $(1598,1613,1628)$ \\
$\mathbf{v}\left(\mathbf{1 4 4 5 - 1 4 6 0} \mathbf{c m}^{-1}\right)$ & 1448 & 1449 & 1444 \\
\hline
\end{tabular}

As shown in table 4 , bands at $1448 \mathrm{~cm}^{-1}$ and $1604 \mathrm{~cm}^{-1}$ were observed at $150^{\circ} \mathrm{C}$ for commercial $\mathrm{PdCl}_{2}$; these bands are characteristic of pyridine strongly bonded by coordination to Lewis acid sites $[38,39]$.

Regarding Eco- $\mathrm{Pd}_{4}{ }^{\circledR}$, the absorption band at $1442 \mathrm{~cm}^{-1}$ disappeared after outgassing at $150^{\circ} \mathrm{C}$ (see supporting data, Fig. S1), which could be attributed to physisorbed pyridine. However, an absorption band at $1444 \mathrm{~cm}^{-1}$ was observed at $150^{\circ} \mathrm{C}$ (table 4) which illustrates pyridine bonded to Lewis acid sites [38]. Several bands were observed between $1598 \mathrm{~cm}^{-1}$ and $1628 \mathrm{~cm}^{-1}$. These bands are more difficult to interpret, but some of them might be assignable to pyridine bonded to Lewis acid sites [38, 39].

Finally, IR spectra of pyridine adsorbed on Eco- $\mathrm{Pd}_{3}{ }^{\circledR}$ show similar absorption bands compared to the spectra obtained with commercial $\mathrm{PdCl}_{2}$ (see supporting data, Fig. S1). Indeed, absorption bands at $1449 \mathrm{~cm}^{-1}$ and 1605 $\mathrm{cm}^{-1}$ were observed at $150^{\circ} \mathrm{C}$ and are characteristic of pyridine bonded by coordination to Lewis acid sites. These two bands are similar to bands observed with $\mathrm{PdCl}_{2}$ even if their frequency is slightly higher. Another band at $1637 \mathrm{~cm}^{-1}$ might indicate the presence of a second type of Lewis acid site, present neither in commercial $\mathrm{PdCl}_{2}$ nor in Eco- $\mathrm{Pd}_{4}{ }^{\circledR}$. As the frequencies of the absorption bands are lower in $\mathrm{PdCl}_{2}$ than in Eco$\mathrm{Pd}_{3}{ }^{\circledR}$, this suggests that Lewis acidity of Eco-Pd ${ }_{3}{ }^{\circledR}$ is stronger than Lewis acidity of $\mathrm{PdCl}_{2}$. 
As a result, Lewis acidity of Eco- $\mathrm{Pd}_{3}{ }^{\circledR}$ seems to be stronger than the one of $\mathrm{PdCl}_{2}$. Besides, by using different thermal treatments to make Eco-Pd ${ }^{\circledR}$, it is possible to obtain two ecocatalysts with different Lewis acid properties, as shown by the two different spectra of pyridine (see supporting data, Fig. S1).

\section{Rearrangement of 2-bromopropiophenone acetal}

Starting from observations concerning acid properties of catalysts and their impact on $\alpha$-arylalkanoic acids synthesis [40], Corma et al. have developed and tested a method to obtain a more detailed view on the acid sites of palladium supported catalysts [37]. The method is based on a model reaction, whose products provide information to assess the hardness and softness of Lewis acid sites. Besides, this reaction can also highlight the ability of catalysts to be hydrolyzed and to form Brønsted acid sites.

The model reaction consists in the rearrangement of the cyclic acetal of $\alpha$-bromopropiophenone 1 (scheme 1). This reaction was tested on Eco- $\mathrm{Pd}_{3}{ }^{\circledR}$ and Eco- $\mathrm{Pd}_{4}{ }^{\circledR}$, and on commercial $\mathrm{PdCl}_{2}$ as reference. Different products were observed in our reaction mixture (Scheme 1, table 5). Two hard Lewis acid products were observed: 2 bromoethyl 2-phenylpropanoate $\mathbf{3}$ and 2-chloroethyl 2-phenylpropanoate 3'. These products are formed because hard Lewis acid sites bind preferentially with the bromine and oxygen atoms according to HSAB principle which leads to aryl migration. Corma et al. only report the presence of 2-hydroxyethyl 2phenylpropanoate as hard Lewis acid product, however, esters $\mathbf{3}$ and $\mathbf{3}$ ' where also observed by Alaerts et al. [41]. Finally, soft Lewis acid sites bind preferentially to bromine and the $\pi$ system of the phenyl ring, leading to alkoxy migration, and thus to the formation of 5-methyl-6-phenyl-2,3-dihydro-1,4-dioxin 4.

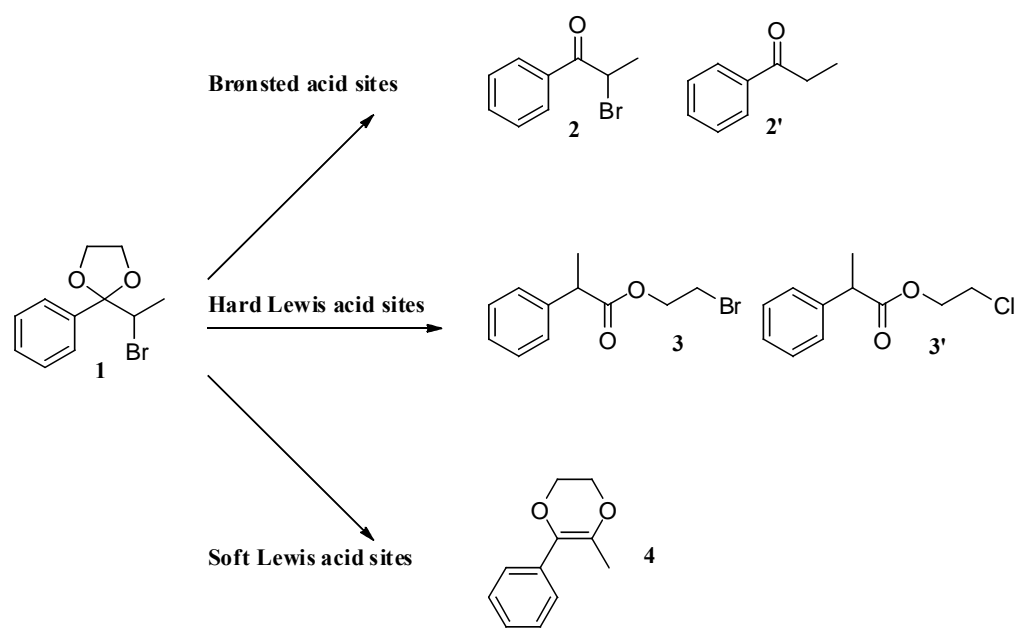

Scheme 1. Reaction of ethylene acetal of 2-bromopropiophenone 1 to $\alpha$-bromopropiophenone $\mathbf{2}$ and propiophenone 2', 2bromoethyl 2-phenylpropanoate 3 and 2-chloroethyl 2-phenylpropanoate 3', 5-methyl-6-phenyl-2,3-dihydro-1,4-dioxin 4.

Table 5. Conversion rate and selectivity of products obtained in reaction mixtures; products are gathered depending on the reactional pathway

\begin{tabular}{cccccc}
\hline Catalysts & Conversion rate (\%) & $\begin{array}{c}\text { Selectivity (\%) } \\
\text { Propiophenone } \\
\text { 2 and 2 }\end{array}$ & $\begin{array}{c}\text { Esters 3 and 3, } \\
\text { Dioxine 4 }\end{array}$ & $\begin{array}{c}\text { Ratio } \\
(\mathbf{3 + 3}): \mathbf{4}\end{array}$ \\
\hline PdCl $_{2}$ & $7 \%$ & $6 \%$ & $0 \%$ & $1 \%$ & $0: 100$ \\
Eco-Pd $^{\circledR}$ & $34 \%$ & $0 \%$ & $29 \%$ & $4 \%$ & $88: 12$ \\
Eco-Pd $^{\circledR}$ & $48 \%$ & $0 \%$ & $41 \%$ & $7 \%$ & $85: 15$ \\
\hline
\end{tabular}

Lewis acidity of $\mathrm{PdCl}_{2}$ is not evidenced here. According to conversion rate, Eco-Pd ${ }^{\circledR}$ activity on cyclic acetal 1 as Lewis acid catalysts is higher than the one observed with $\mathrm{PdCl}_{2}$. Thus, Lewis acidity of Eco-Pd ${ }^{\circledR}$ seems stronger than Lewis acidity of $\mathrm{PdCl}_{2}$. These results are in accordance with pyridine adsorption studies, which suggested that acid properties of Eco- $\mathrm{Pd}^{\circledR}$ and $\mathrm{PdCl}_{2}$ are different. Finally, the ratio $(3+3$ ') to 4 highlights that Lewis acid sites of Eco-Pd ${ }_{4}{ }^{\circledR}$ are softer than those of Eco-Pd ${ }_{3}{ }^{\circledR}$. 


\section{XPS analysis}

XPS analysis was performed on each sample to study the oxidation states of palladium in the Eco-Pd ${ }^{\circledR}$ catalysts as a function of the thermal treatment. The Pd 3d core level signals were systematically decomposed into different contributions which are summarized in table 6 (binding energies of $\mathrm{Pd} 3 \mathrm{~d}_{5 / 2}$ component of each doublet, separated by a splitting of $5.2 \mathrm{eV}$ ).

Table 6. Pd $3 \mathrm{~d}_{5 / 2}$ binding energies obtained after decomposition of Pd $3 \mathrm{~d}$ core levels.

\begin{tabular}{cc}
\hline Ecocatalysts & Pd 3d $_{5 / 2}$ \\
\hline Eco-Pd $_{1}{ }^{\circledR}$ & $337.1 \pm 0.1 \mathrm{eV}$ \\
& $339.7 \pm 0.1 \mathrm{eV}$ \\
& \\
Eco-Pd $_{2}{ }^{\circledR}$ & $336.0 \pm 0.1 \mathrm{eV}$ \\
& \\
Eco-Pd $_{3}{ }^{\circledR}$ & $336.4 \pm 0.1 \mathrm{eV}$ \\
& $338.4 \pm 0.1 \mathrm{eV}$ \\
& \\
Eco-Pd $_{4}{ }^{\circledR}$ & $335.3 \pm 0.1 \mathrm{eV}$ \\
\hline
\end{tabular}

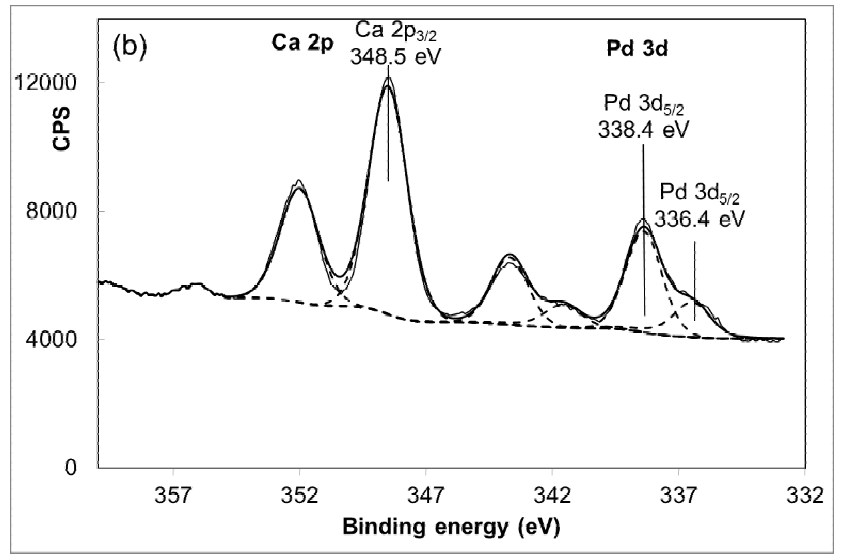

Figure 1. Ca $2 p$ and Pd $3 d$ core levels XPS spectrum for Eco-Pd ${ }_{3}^{\circledR}$

The Pd 3d signal of Eco-Pd ${ }_{1}^{\circledR}$ consists of a combination of two doublets (see supporting data, Fig. S2). The more intense one is characterized by a $\mathrm{Pd} 3 \mathrm{~d}_{5 / 2}$ binding energy (BE) of $337.1 \pm 0.1 \mathrm{eV}$, indicating presence of $\mathrm{Pd}(\mathrm{II})$, which is assumed to be $\mathrm{PdO}$ according to published data [42-44]. This is coherent with an oxidative thermal treatment under air flow. The doublet located at a $\mathrm{Pd} 3 \mathrm{~d}_{5 / 2} \mathrm{BE}$ of $339.7 \pm 0.1 \mathrm{eV}$ has a lower intensity (about $10 \%$ of the main peak) and may be assigned to a satellite of $\mathrm{PdO}$ in the $\mathrm{Pd} 3 \mathrm{~d}_{5 / 2}$ signal which is mentioned by Pillo et al. [44]. This hypothesis is reinforced by its BE position, at $2.6 \mathrm{eV}$ from the main contribution, as stated by Pillo et al.

The Pd $3 \mathrm{~d}$ signal of Eco-Pd ${ }_{2}{ }^{\circledR}$ is mainly composed by one asymmetric doublet located at a BE of $336.0 \pm 0.1$ $\mathrm{eV}$ (see supporting data Fig. S2). The spectrum is characteristic of $\mathrm{Pd}$ in the metallic state $\mathrm{Pd}(0)$; even if the BE is in the higher range of the $\mathrm{BE}$ values of metallic $\mathrm{Pd}$ found in public data [42, 43], it remains coherent with binding energies reported by Bertolini et al. for $\mathrm{Pd} / \mathrm{C}$ [45]. The peak decomposition also shows in the high $\mathrm{BE}$ part that an oxidized $\mathrm{Pd}$ contribution ( $\mathrm{PdO}$ ) could also be present in the sample, though very weak. Thus, thermal treatment under argon flow is a reducing treatment for palladium in the ashes. 
In the case of $\mathrm{Eco}-\mathrm{Pd}_{3}{ }^{\circledR}$ (obtained after $\mathrm{HCl}$ treatment of Eco-Pd ${ }_{1}^{\circledR}$ ), the Pd $3 \mathrm{~d}$ core level presents two contributions, the binding energies of which being characteristic of Pd(II) (see supporting data Fig. S2). The low $\mathrm{BE}$ contributions, with a $\mathrm{BE}$ of $336.4 \pm 0.1 \mathrm{eV}$, could be also assigned to $\mathrm{PdO}$, as in Eco- $\mathrm{Pd}_{1}{ }^{\circledR}$, though in the lower range of the BEs that can be found in the published data [43]. The second contribution, at a higher BE of $338.4 \pm 0.1 \mathrm{eV}$, indicates that a second species of palladium (II) is present in the ecocatalyst, which is assumed to be a complexe of palladium with chlorine formed with $\mathrm{HCl}$ treatment. An intense $\mathrm{Cl} 2 \mathrm{p}$ doublet (not shown) confirms the present of a chlorine compounds in the catalysts. It is also possible that the BE shift of the $\mathrm{Ca} 2 \mathrm{p}_{3 / 2} \mathrm{BE}$ (about $1 \mathrm{eV}$ higher than in the other samples) is also due to the formation of $\mathrm{CaCl}_{2}$ during the treatment, which seems to be coherent with $\mathrm{BE}$ reported in literature [46, 47]. It must be noted that it is the more intense contribution to the total Pd $3 \mathrm{~d}$ core level spectrum, that is why a satellite of PdO has not been added to the spectrum: its intensity would not be significant and it would largely overlap with the Pd-chlorine feature.

The weak Pd 3d signal of Eco-Pd ${ }_{4}^{\circledR}$ (obtained after $\mathrm{HCl}$ treatment of Eco- $\mathrm{Pd}_{2}{ }^{\circledR}$ ), presenting a low signal to noise ratio (see suporting data fig. S2), also decomposed with two contributions, presents a minor metallic contribution at $335.3 \pm 0.1 \mathrm{eV}[42,43]$. The second feature located at $337.8 \pm 0.1 \mathrm{eV}$, slightly more intense, indicates the presence of $\mathrm{Pd}(\mathrm{II})$ in the catalyst in addition to metallic Pd. It is assumed that a Pd-chlorine compound has been formed by the $\mathrm{HCl}$ treatment, as in the previous case of $\mathrm{Eco}-\mathrm{Pd}_{3}{ }^{\circledR}$. The $\mathrm{Cl} 2 \mathrm{p}$ core level is also detected in this case: it is composed by 2 doublets, most probably characteristic of both a Pd-chlorine adsorbed compound as well as an organic $\mathrm{Cl}$-containing compound.

The fact that metallic palladium is present in Eco- $\mathrm{Pd}_{4}{ }^{\circledR}$ and not in Eco-Pd ${ }_{3}{ }^{\circledR}$ might explain that the Lewis acidity of Eco- $\mathrm{Pd}_{4}{ }^{\circledR}$ is softer than the Lewis acidity of Eco-Pd ${ }_{3}{ }^{\circledR}$, as shown in the previous section with the cyclic acetal rearrangement.

Thermal treatment of plants'roots used to produce Eco-Pd ${ }^{\circledR}$ influences oxidation states of palladium present in Eco-Pd ${ }^{\circledR}$ : under air flow, only $\mathrm{Pd}(\mathrm{II})$ is present, whereas metallic $\mathrm{Pd}$ is observed with thermic treatment under argon flow.

\section{XRD analysis}

XRD analysis of Eco-Pd ${ }_{3}^{\circledR}$ and Eco-Pd ${ }_{4}^{\circledR}$ was performed to identify palladium species under crystalline form. There was no crystallized phase in Eco- $\mathrm{Pd}_{4}{ }^{\circledR}$ thus XRD analysis was not useful to identify palladium species. However, XRD diffractogram of Eco-Pd ${ }_{3}^{\circledR}$ (Fig. 2) clearly indicates presence of PdO which is in accordance with XPS analysis. Diffractogram also shows presence of $\mathrm{K}_{2} \mathrm{PdCl}_{4}$, which is a masked form of $\mathrm{PdCl}_{2}$, often used as a soluble form of $\mathrm{PdCl}_{2}$ and as starter point for palladium nanoparticles synthesis [48]. This result supports XPS analysis described previously. Indeed, Kumar et al. [49] reported a $\mathrm{Pd} 3 \mathrm{~d}_{5 / 2}$ binding energy of $338.4 \mathrm{eV}$ for $\mathrm{K}_{2} \mathrm{PdCl}_{4}$, which perfectly corresponds to the binding energy of the second contribution of Pd $3 \mathrm{~d}$ core level observed with Eco-Pd ${ }_{3}^{\circledR}$ (see previous section XPS analysis).

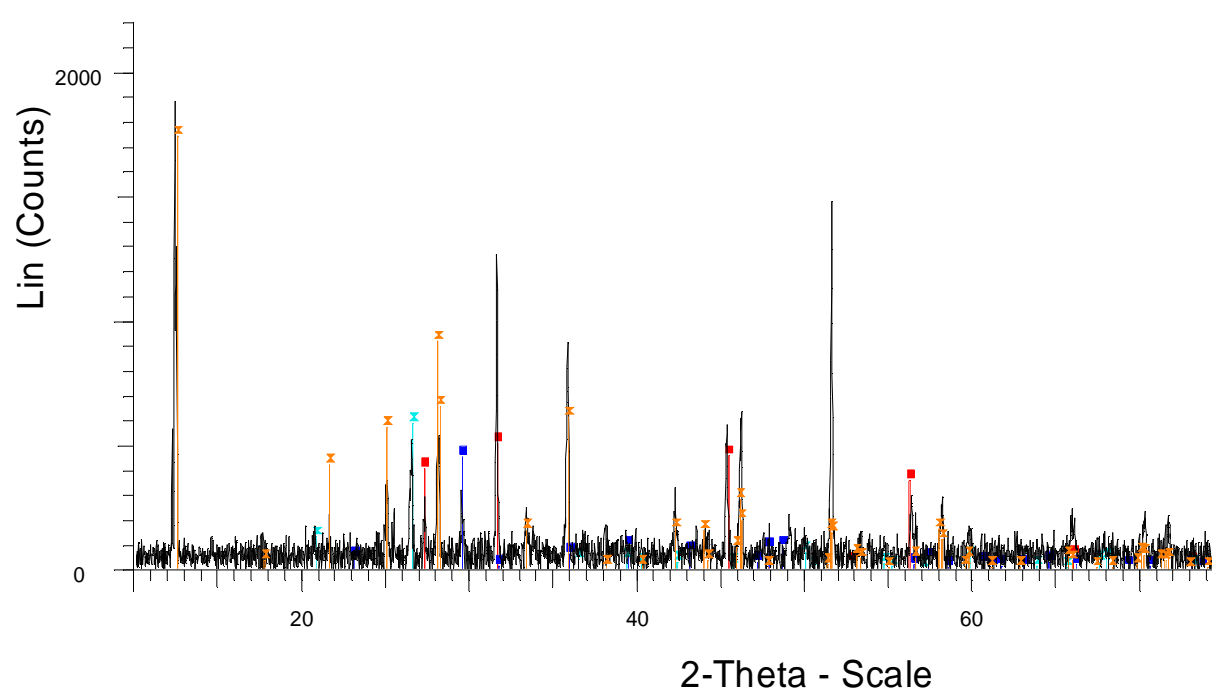

Potassium Tetrachloropalladate (II) $-\mathrm{K}_{2} \mathrm{PdCl}_{4}$

1 Palladium Oxide - PdO

$\square_{1}$ Calcite $-\mathrm{CaCO}_{3}$

I. Quartz $-\mathrm{SiO}_{2}$ 
Figure 2. XRD diffraction pattern of Eco- $\mathrm{Pd}_{3}{ }^{\circledR}$

SEM and TEM analysis

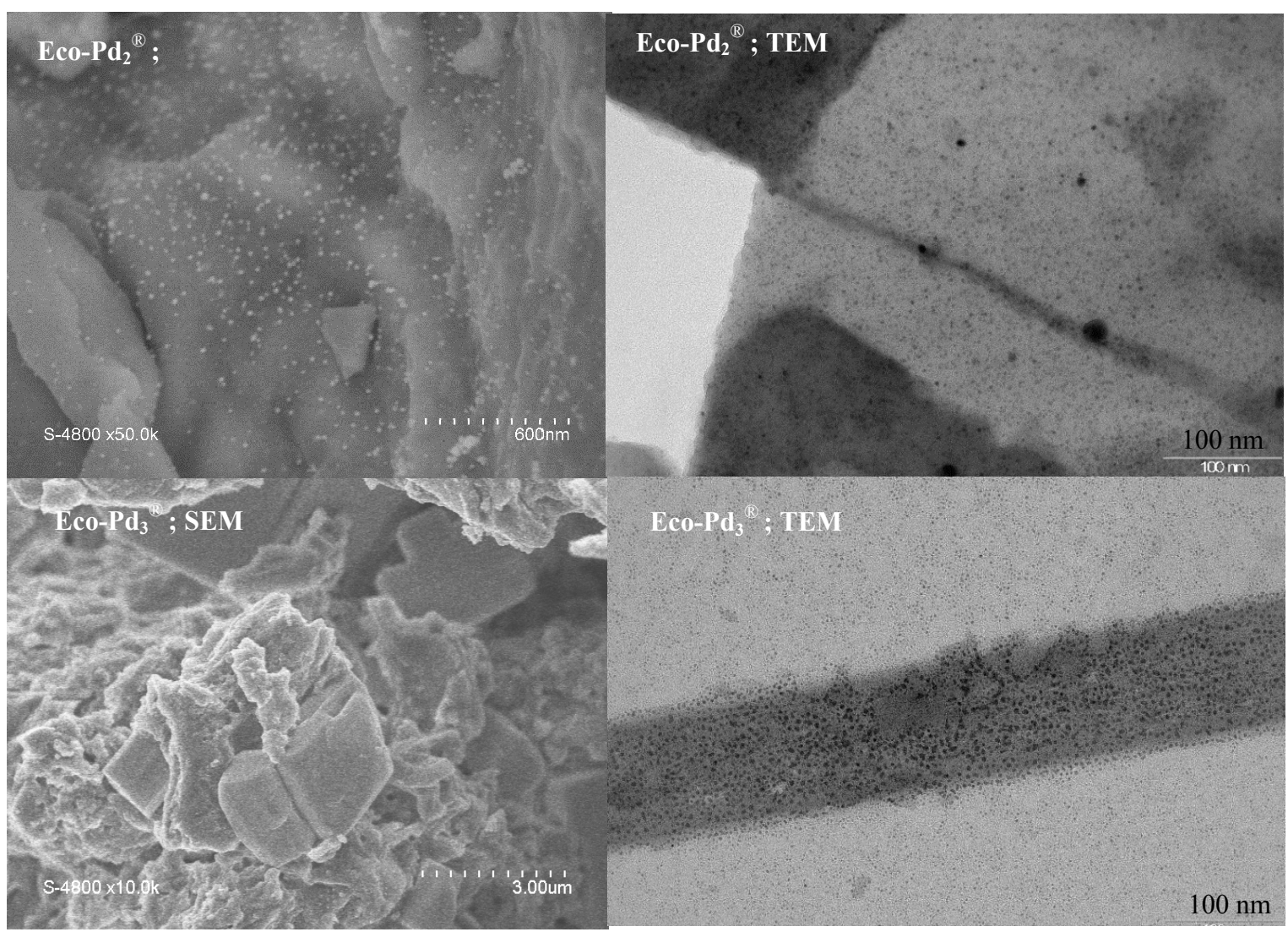

Figure 3. SEM and TEM images of Eco- $\mathrm{Pd}_{2}{ }^{\circledR}$ and Eco- $\mathrm{Pd}_{3}{ }^{\circledR}$

SEM and TEM images show contrasts depending on atomic-number of the elements that compose particles. Elements with high atomic number are brighter on SEM images and darker on TEM images. The ecocatalysts were characterized via electron microscopies. The SEM and TEM images of Eco-Pd ${ }^{\circledR}$ and Eco-Pd ${ }^{\circledR}$ are shown in Figure 3, whereas the SEM and TEM images of Eco-Pd ${ }_{1}^{\circledR}$ and Eco- $\mathrm{Pd}_{4}{ }^{\circledR}$ are given in the supporting data (Fig. S3).

SEM images indicate that all Eco-Pd ${ }^{\circledR}$ consist of a matrix made of agglomerated micrometric sized particles of biosourced material. Some large objects may be due to the formation of crystalline mineral salt. As shown in the SEM-image of material Eco-Pd ${ }_{2}^{\circledR}$ (Fig. 3, upper left), small particles of nanometric size are visible at the surface of the matrix, which principally consist of palladium, as shown in EDS analysis (see next section).

TEM images confirm the results of SEM analyses and show nanoparticles which are embedded in solid matrix. These nanoparticles are well dispersed at the surface of the matrix. However, in some portion of the material the number of the nanoparticles is lower than the number observed on TEM images (Fig. 3). 
For each material, the average particle size has been determined on the base of at least 32 particles (table 7). Particle size distribution has been studied for Eco- $\mathrm{Pd}_{2}{ }^{\circledR}$ and Eco- $\mathrm{Pd}_{3}{ }^{\circledR}$ on the base of 100 particles (Fig. 4). The particles show a relatively narrow size distribution centered between 2 and $8 \mathrm{~nm}$ (table 7 and Fig. 4).

Table 7. Average particle size in nm measured on TEM images

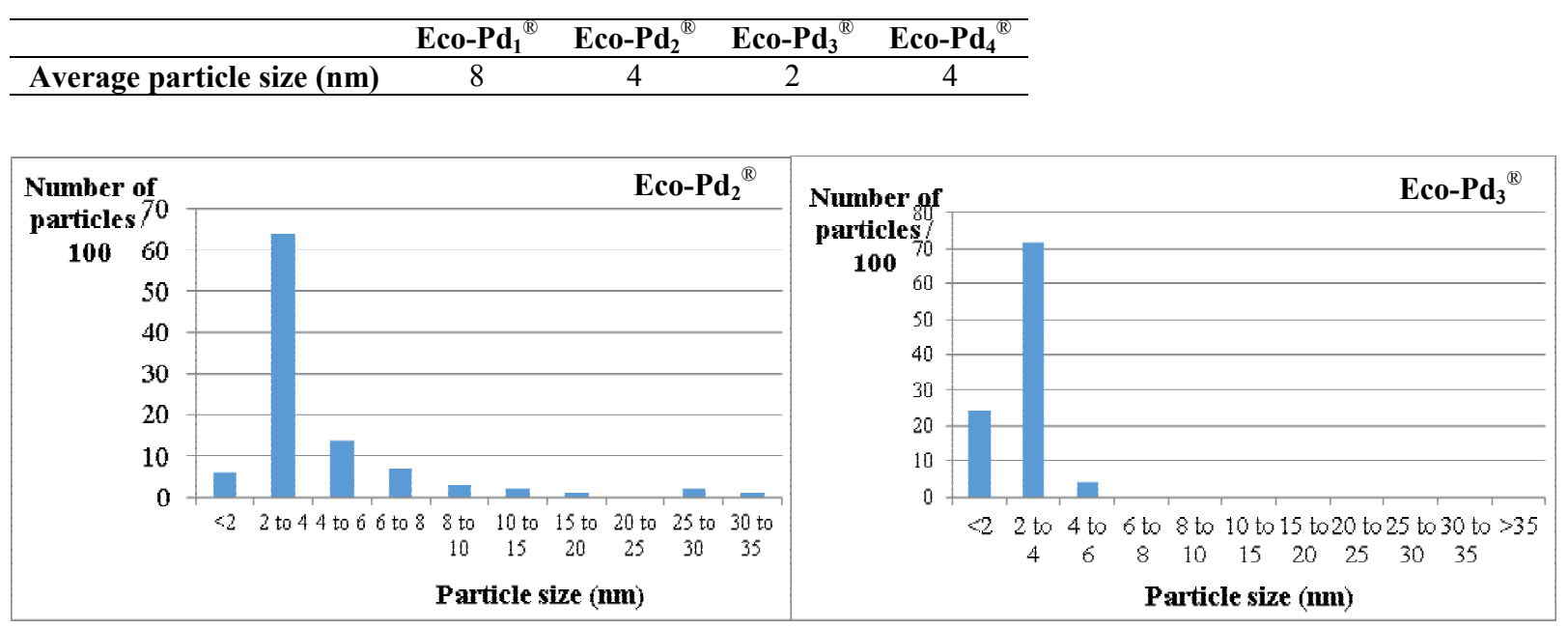

Figure 4. Particle size distribution (100 particles) in $\mathrm{Eco}-\mathrm{Pd}_{2}{ }^{\circledR}$ and $\mathrm{Eco}-\mathrm{Pd}_{3}{ }^{\circledR}$

\section{EDS analysis}

The elemental composition of particles observed in TEM and SEM images was assessed by EDS analysis (see supporting data Fig. S4). The analyzed particles have been randomly chosen on the observed sample. Even though the analyzed particles are not representative for the whole Eco-Pd ${ }^{\circledR}$ catalyst, this EDS study may give some valuable information concerning the chemical composition of the support matrix and the embedded nanoparticles. As EDS analysis is a semi-quantitative method, we only qualitatively determined the presence of each element.

Table 8 summarizes the elements present in the nanoparticles observed on Eco-Pd ${ }^{\circledR}$ catalysts in TEM images (Fig. 3), and also gives the elemental composition of the biosourced matrix. We only indicate when palladium is the most abundant element present in the analyzed area.

Table 8. Qualitative elemental composition of nanoparticles and matrix

\begin{tabular}{|c|c|c|}
\hline & Elemental composition of particles & Elemental composition of the matrix \\
\hline$\overline{\text { Eco-Pd }}$ & Pd (most abundant), O, S, Ca, Fe, Na, Mg, K, Al & $\mathrm{Mg}, \mathrm{P}, \mathrm{O}, \mathrm{S}, \mathrm{K}, \mathrm{Ca}, \mathrm{Al}, \mathrm{Na}, \mathrm{Cl}$ \\
\hline Eco-Pd ${ }_{2}$ & $\begin{array}{l}\mathrm{N}, \mathrm{Na}, \mathrm{Pd} \text { (most abundant after } \mathrm{N} \text { and } \mathrm{Na} \text { ), } \mathrm{O}^{\mathrm{a}}, \mathrm{Al}, \mathrm{S}, \mathrm{P}, \mathrm{K} \text {, } \\
\mathrm{Fe}, \mathrm{Mg}\end{array}$ & - \\
\hline Eco- $-\mathrm{Pd}_{3}$ & Pd (most abundant), $\mathrm{Cl}, \mathrm{Na}, \mathrm{O}$ & $\mathrm{Pd}$ (most abundant), $\mathrm{Cl}, \mathrm{Na}, \mathrm{O}$ \\
\hline Eco- $-\mathrm{Pd}_{4}$ & Pd (most abundant), $\mathrm{P}, \mathrm{Cl}, \mathrm{Ca}, \mathrm{Fe}, \mathrm{Na}, \mathrm{S}, \mathrm{O}^{\mathrm{a}}$ & $\mathrm{O}, \mathrm{P}, \mathrm{Cl}$ \\
\hline
\end{tabular}


It clearly appears that in all Eco-Pd ${ }^{\circledR}$ materials, the nanoparticles observed on SEM and TEM images (Fig. 3) mainly contain palladium species.

In Eco-Pd ${ }_{1}^{\circledR}$, palladium is mainly associated to oxygen (which is coherent with XPS results) and with alkaline elements and alkaline earth metals. In Eco-Pd ${ }_{2}^{\circledR}$, particles mainly contain nitrogen and sodium, but palladium is also present. Some nanoparticles do not contain oxygen, which is in accordance with the presence of $\operatorname{Pd}(0)$ species as highlighted by XPS studies. The nanoparticles in Eco-Pd ${ }_{3}^{\circledR}$ only contain four elements: $\mathrm{Pd}, \mathrm{Cl}, \mathrm{Na}$ and O. This result well supports XRD and XPS analyses. Potassium is not observed contrarily to sodium suggesting that $\mathrm{Na}_{2} \mathrm{PdCl}_{4}$ is formed as well as $\mathrm{K}_{2} \mathrm{PdCl}_{4}$ which is observed by XRD. These nanoparticles are embedded in a matrix with a very similar composition. The matrix is probably amorphous, and the nanoparticles are crystalline. Other elements observed by ICP-MS in Eco-Pd ${ }_{3}^{{ }^{B}}$ (see ICP-MS analysis of Eco$P d^{\circledR}$ section 3.2.), such as calcium or aluminum are not observed with EDS analysis performed here. Finally, palladium is the most abundant element present in particles observed in Eco-Pd ${ }_{4}^{\circledR}$. Some particles do not contain oxygen, which might support XPS studies and the presence of $\operatorname{Pd}(0)$.

Nanometric particles located and well dispersed on the surface of Eco-Pd ${ }^{\circledR}$ are essentially made of palladium and constitute active catalytic sites.

In conclusion, thermal treatment used to produce Eco-Pd ${ }^{\circledR}$ catalysts completely influences the physical properties of the formed materials. Thermal treatment under argon flow leads to Eco-Pd ${ }^{\mathbb{B}}$ materials containing metallic Pd, whereas thermal treatment under air flow leads to ecocatalysts in which Pd is only present as $\mathrm{Pd}(\mathrm{II})$ species. Hydrochloric acid treatment allows the formation of a particular tetrachloropalladate complex observed in Eco-Pd ${ }_{3}^{\circledR}$, which can be useful in organic synthesis due to its high solubility. Eco-Pd ${ }^{\circledR}$ obtained after $\mathrm{HCl}$ treatment show a stronger Lewis acidity than commercial $\mathrm{PdCl}_{2}$, and thus present a real interest for organic synthesis applications. Finally, all Eco-Pd ${ }^{\circledR}$ contain well dispersed nanosized palladium particles embedded in a biosourced support. This dispersion increases the accessibility of the nanoparticles, which is a huge asset for organic synthesis.

\subsection{Reactivity of Eco-Pd $d^{\circledR}$ in Suzuki-Miyaura and Heck-Mizoroki coupling reaction}

Among palladium-catalyzed reactions, the Suzuki-Miyaura reaction (cross-coupling of aryl halides with boronic acids) and the Heck-Mizoroki reaction (cross-coupling of aryl halides with alkenes) are among the most powerful tools for the selective construction of carbon-carbon bonds. Both reactions are characterized by an exceptionally broad functional group tolerance, the use of readily available and easy to handle reagents and finally high product yields combined with high selectivities [12, 50, 51]. Suzuki-Miyaura and Heck-Mizoroki reactions allow accessing structural units found in a wide range of pharmaceuticals, agrochemicals, and natural products as well as in conducting polymers and liquid crystalline materials. Since the first reports on palladiumcatalyzed coupling of aryl halides with arylboronic acids [7, 52], on the one side and the arylation of carboncarbon double bonds on the other side $[6,53]$, the improvement of the reaction conditions for these reactions receives constant attention.

Traditional catalysts for Suzuki-Miyaura and Heck-Mizoroki coupling reactions generally involve palladium (0) species coordinated by ligands such as phosphines or amines. These ligands allow increasing the electron density on the Pd center, which may in turn accelerate the oxidative addition step and therefore improve the reaction rate while decreasing the amount of palladium [54]. However, the principal drawbacks of homogeneous $\operatorname{Pd}(0)$ catalysts are related to their rather high price and their limited stability. Furthermore, homogeneous palladium (0) catalysts are usually not re-usable and the reaction products are frequently contaminated by residual palladium and the used ligands, often difficult to separate from the reaction products $[51,55]$.

To overcome these difficulties, reusable heterogeneous and/or ligand-free palladium catalysts have been developed. $\mathrm{Pd} / \mathrm{C}$ is one of the most common heterogeneous catalysts because of its availability, easy handling, and re-usability. The use of $\mathrm{Pd} / \mathrm{C}$ as catalyst in Suzuki-Miyaura and Heck-Mizoroki coupling reactions has intensively been studied [56]. However, the principal drawback of this catalyst is related to its preparation and manipulation hazards, as $\mathrm{Pd} / \mathrm{C}$ is pyrophoric in the presence of solvents [57]. Furthermore, the necessity to use of high quantities of catalyst (1-5 mol\% of palladium) has been reported by several authors [56]. 
In recent years, great interest has been devoted to the use of metal nanoparticles as catalysts for C-C coupling reactions. This research is motivated by the better electron donating ability of nanoparticles and a higher surface area-to-volume ratio [58]. In principle, the catalytic activity in nanocatalysis is determined by the size of the nanoparticles. In addition, metal nanoparticles also offer the general advantages of heterogeneous catalysts which are easy recovery and recyclability. Numerous reports showed that pre-formed nanoparticles of palladium (0) immobilized on various organic or mineral support can activate aryl bromides and chlorides for cross-coupling reaction $[59,60]$. However, this approach necessitates the use of sophisticated support and preor in situ reduced Pd nanoparticles.

Numerous attempts have been made to develop ligand-free non-supported palladium (II) catalyst systems for cross-coupling reactions. Homogeneous $\operatorname{Pd}($ II) catalyst systems can promote Suzuki-Miyaura and HeckMizoroki reactions with aryl bromides at low catalyst concentrations (0.01-0.02 $\mathrm{mol} \%$ of Pd). In contrast, in the case of Suzuki-Miyaura reactions, the activation of highly activated aryl chlorides necessitates the aid of additives such as surfactants or polymers [61]. The term "homeopathic palladium" was originally introduced by Beletskaya for these reactions where very low loadings of palladium can be used [12, 62].

Few examples of $\mathrm{Pd}(\mathrm{II})$ ligand- and additive-free reactions are reported. However, these reactions required a high amount of palladium (0.5-5 mol \%) [63-65].

A recent report described the recovery of palladium nanoparticles from laboratory plants. This work used only pyrolytic steps under inert atmosphere in order to generate Pd nanoparticles and therefore considerably simplified the access to Pd nanoparticles compared to traditional nanoparticles syntheses [66]. These heterogeneous plant catalysts have displayed interesting catalytic activity in Suzuki-Miyaura coupling reactions between phenylboronic acid and various iodo-, bromo- and chloroarenes. However, in this study, high amounts of palladium (12\% mol of Pd) were necessary together with use of 1.6 eq of TBAB, which acts as phase transfer agent and as stabiliser for the PdNPs.

Table 9. Suzuki-Miyaura cross-couling of aryl iodides and bromides with phenylboronic acid. ${ }^{\mathrm{a}}$

Entry Aryl halide $\mathrm{Pd}(\mathrm{mol} \%)$


5<smiles>CC(=O)c1ccc(Br)cc1</smiles>

6<smiles>O=Cc1ccc(Br)cc1</smiles>

7<smiles>CC(=O)c1ccc(Br)cc1</smiles>

8<smiles>N#Cc1ccc(Br)cc1</smiles>

12<smiles>CC(=O)c1ccc(-c2ccccc2)cc1</smiles><smiles>O=Cc1ccc(-c2ccccc2)cc1</smiles><smiles>CC(=O)c1ccc(-c2ccccc2)cc1</smiles>

${ }^{\mathrm{a}}$ Reaction conditions: Eco- $\mathrm{Pd}_{3}{ }^{\circledR}$, phenyl boronic acid (1.2 equiv), potassium phosphate ( 3 equiv), toluene, $100{ }^{\circ} \mathrm{C}, 15 \mathrm{~h}$.

${ }^{\mathrm{b}}$ GC-MS.

${ }^{\mathrm{c}}$ Reaction conditions: $\mathrm{Pd}(\mathrm{OAc})_{2}$, phenyl boronic acid (1.2 equiv), cesium carbonate ( 2 equiv), $\mathrm{H}_{2} \mathrm{O}, 125^{\circ} \mathrm{C}, 12 \mathrm{~h}$.

${ }^{\mathrm{d}}$ Reaction conditions: Pd-P-300, phenyl boronic acid (1.2 equiv), sodium carbonate (3.3 equiv), EtOH/ $\mathrm{H}_{2} \mathrm{O} 2 / 1, \mathrm{TBAB}$ (1.7 equiv), $55^{\circ} \mathrm{C}$.

${ }^{\mathrm{e}}$ Reaction conditions: $\mathrm{PdCl}_{2}$, phenyl boronic acid (1.5 equiv), potassium phosphate ( 3 equiv), toluene, $100{ }^{\circ} \mathrm{C}, 8 \mathrm{~h}$.

${ }^{\mathrm{f}}$ Reaction conditions: $\mathrm{Pd}(\mathrm{OAc})_{2}$, phenyl boronic acid (1.5 equiv), potassium carbonate (1 equiv), $\mathrm{NMP} / \mathrm{H}_{2} \mathrm{O} 19 / 1,90{ }^{\circ} \mathrm{C}$, 4h.

${ }^{\mathrm{g}}$ Reaction conditions: $\mathrm{Pd} / \mathrm{C}$, phenyl boronic acid (1.2 equiv), sodium carbonate (1 equiv), NMP/ $\mathrm{H}_{2} \mathrm{O} 10 / 4,120{ }^{\circ} \mathrm{C}, 1.5 \mathrm{~h}$.

Table 10. Suzuki-Miyaura cross-couling of aryl chlorides with phenylboronic acid. ${ }^{\text {a }}$

Entry Aryl halide $\quad \mathrm{Pd}(\mathrm{mol} \%)$


4

5

6

7

(1)
1.1<smiles>N#Cc1ccc(-c2ccccc2)cc1</smiles>

This work<smiles>N#Cc1ccc(-c2ccccc2)cc1</smiles>

81<smiles>O=Cc1ccc(-c2ccccc2)cc1</smiles>

Trace [68]<smiles>N#Cc1ccc(-c2ccccc2)cc1</smiles>

98

${ }^{\mathrm{a}}$ Reaction conditions: Eco- $\mathrm{Pd}_{3}{ }^{\circledR}$, phenyl boronic acid (1.2 equiv), potassium phosphate ( 3 equiv), toluene, $100{ }^{\circ} \mathrm{C}, 15 \mathrm{~h}$.

${ }^{\mathrm{b}} \mathrm{GC}-\mathrm{MS}$

${ }^{\mathrm{c}} \mathrm{Eco}_{\mathrm{Pd}}{ }^{\circledR}$ prepared under argon.

${ }^{\mathrm{d}}$ Reaction conditions: Pd-P-300, phenyl boronic acid (1.2 equiv), sodium carbonate (3.3 equiv), EtOH/ $\mathrm{H}_{2} \mathrm{O} 2 / 1, \mathrm{TBAB}$ (1.7 equiv), $55^{\circ} \mathrm{C}$.

${ }^{\mathrm{e}}$ Reaction conditions: $\mathrm{PdCl}_{2}$, phenyl boronic acid (1.5 equiv), potassium phosphate ( 3 equiv), toluene, $100{ }^{\circ} \mathrm{C}, 8 \mathrm{~h}$.

${ }^{\mathrm{f}}$ Reaction conditions: $\mathrm{Pd} / \mathrm{C}$, phenyl boronic acid (1.2 equiv), $\mathrm{NaOH}$ (1.2 equiv), $\mathrm{NMP} / \mathrm{H}_{2} \mathrm{O} 10 / 4,120^{\circ} \mathrm{C}, 4 \mathrm{~h}$.

In order to demonstrate the potential of Eco-Pd ${ }^{\circledR}$ catalyst, we decided to study its capacity to promote crosscoupling reactions. At first, we investigated the catalytic activity of Eco-Pd ${ }_{3}^{\circledR}$ as its synthetic protocol avoid the use of inert atmosphere during the thermal treatment (as in the case of Eco-Pd ${ }_{4}^{\circledR}$ ). Catalytic activities of Eco$\mathrm{Pd}_{1}{ }^{\mathbb{B}}$ and Eco-Pd ${ }_{2}{ }^{\circledR}$ have not been studied as it is well known that $\mathrm{Pd}(\mathrm{II})$ oxide fail to promote cross-coupling reactions unlike others $\mathrm{Pd}(\mathrm{II})$ catalysts as $\mathrm{PdCl}_{2}$ or $\mathrm{Pd}(\mathrm{OAc})_{2}$ [63].

We observed that Eco-Pd ${ }_{3}{ }^{\circledR}$ displays very high catalytic activity in Suzuki-Miyaura coupling reactions between phenylboronic acid and various iodo-, bromo- and chloroarenes (tables 9-10). These results are particularly appealing when compared to other ligand- and additive-free palladium catalysts described in the literature (tables 9-10). Moreover, the reaction conditions employed with the Eco- $\mathrm{Pd}_{3}{ }^{\circledR}$ catalyst are particularly mild, avoiding in particular the use of strong bases and involving very low catalyst quantities. As an example, the coupling reaction of phenylboronic acid with 4-bromoacetophenone yielded the cross-coupling product 4acetylbiphenyl in $73 \%$ yield despite the use of only $0.0025 \mathrm{~mol} \%$ of Pd (table 9, entry 4). Furthermore, the Eco$\mathrm{Pd}_{3}{ }^{\circledR}$ catalyst is able to activate several chloroarenes in Suzuki-Miyaura reactions. Coupling reactions involving 4-chloro-benzonitrile and phenylboronic acid led to the formation of 4-cyanobiphenyl in up to $76 \%$ yield (table 10 , entry 4). However, a higher amount of catalyst was necessary to promote this reaction. These results are particularly promising as to date, no other ligand- and additive-free Pd(II) catalysts systems capable to activate arylchlorides is reported in the literature. A similar reaction involving $\mathrm{Pd} / \mathrm{C}$ as catalyst and $\mathrm{NaOH}$ as base gave high conversion but suffers from harsh reaction conditions (table 10, entry 7).

In the following, we attempted to optimize the reaction conditions by using the catalyst Eco-Pd ${ }_{4}^{\circledR}$ instead of Eco-Pd ${ }_{3}{ }^{\circledR}$. The Eco-Pd ${ }^{\circledR}$ material was prepared under inert argon atmosphere. However, the catalytic test with Eco-Pd ${ }_{4}^{\circledR}$ showed considerably decreased product formation and yielded the cross-coupling product in only $9 \%$ yield (table 10, entry 3 ).

To test the stability of Eco-Pd ${ }_{3}^{\circledR}$, the recycling possibility of this catalyst has been carried out in the coupling reaction between phenylboronic acid and 4-iodoanisole (table 9, entry 1). After one cycle, Eco-Pd ${ }_{3}^{\circledR}$ was separated by filtration, and was then used in the same fashion. The reaction gave $62 \%$ yield instead $73 \%$. The catalytic activity of Eco- $\mathrm{Pd}_{3}{ }^{\circledR}$ is minimally affected, signifying that the catalyst presented a good stability. 
In conclusion, the Eco-Pd ${ }_{3}^{\circledR}$ catalyst shows significantly high catalytic activity compared to laboratory plantbased catalysts recently described by Clark et al. Contrary to this previous work, our methodology allows performing Suzuki-Miyaura reactions with considerably lower amount of catalyst and in the absence of additives such as n-tetrabutylammonium bromide (TBAB). These results are due to homogeneous dispersion of $\mathrm{Pd}(\mathrm{II})$ species embedded in a biosourced support, as shown by the characterization of the Eco-Pd ${ }^{\circledR}$ materials via electron microscopy (see SEM and TEM analysis section 3.2). Furthermore, the comparison of the catalytic properties of the Eco- $\mathrm{Pd}_{3}{ }^{\circledR}$ and Eco-Pd ${ }_{4}{ }^{\circledR}$ materials indicated that a thermal treatment under inert atmosphere is not mandatory, contrary to the previous study of Suzuki-Miyaura coupling with laboratory plant-based catalysts [66]. Our results even showed that a catalyst preparation under air is favorable to achieve high catalytic activity in Suzuki-Miyaura coupling (table 10, entries 2-3). $\mathrm{Eco}-\mathrm{Pd}_{3}{ }^{\circledR}$ is a very efficient and versatile catalyst for crosscoupling reactions with a simple and straightforward preparation protocol. To date, Eco- $\mathrm{Pd}_{3}{ }^{\circledR}$ is the most active ligand- and additive-free Pd(II) catalyst with arylchlorides.

In a second time, we studied the use of the Eco-Pd ${ }^{\circledR}$ catalysts in the Heck-Mizoroki cross-coupling reaction, as this reaction is one of the most representative coupling reactions and generally studied to assess the potential of Pd catalysts.

Table 11. Screening of reaction conditions on the Heck-Mizoroki reaction catalyzed by Eco-Pd ${ }_{3}^{\circledR}$

\begin{tabular}{|c|c|c|c|c|c|c|c|c|}
\hline Entry $^{\mathrm{a}}$ & $\begin{array}{l}\mathrm{Pd} \\
(\mathrm{mol} \%)\end{array}$ & Base & Solvent & Atmosphere & Ligand & Additive & $\begin{array}{l}\text { Conversion } \\
(\%)^{b}\end{array}$ & $\begin{array}{l}\text { Selectivity } \\
(\%)^{\mathrm{b}}\end{array}$ \\
\hline 1 & 0.05 & $\mathrm{NaOAc}$ & NMP & $\mathrm{N}_{2}$ & - & - & 25 & 84 \\
\hline 2 & 0.2 & $\mathrm{NaOAc}$ & NMP & $\mathrm{N}_{2}$ & - & - & 8 & 75 \\
\hline 3 & 0.05 & $\mathrm{NaOAc}$ & NMP & $\mathrm{N}_{2}$ & - & $\mathrm{I}_{2}{ }^{\mathrm{c}}$ & 35 & 91 \\
\hline 4 & 0.05 & $\mathrm{Et}_{3} \mathrm{~N}$ & NMP & $\mathrm{N}_{2}$ & - & $\mathrm{I}_{2}^{\mathrm{c}}$ & 0 & $n d^{d}$ \\
\hline 5 & 0.05 & $\mathrm{NaOAc}$ & NMP & $\mathrm{N}_{2}$ & - & $\mathrm{TBAB}^{\mathrm{e}}$ & 43 & 88 \\
\hline 6 & 0.05 & $\mathrm{NaOAc}$ & NMP & Air & - & $\mathrm{TBAB}^{\mathrm{e}}$ & 4 & $\mathrm{nd}^{\mathrm{d}}$ \\
\hline 7 & 0.05 & $\mathrm{NaOAc}$ & $\mathrm{NMP} / \mathrm{H}_{2} \mathrm{O}$ 5:1 & $\mathrm{N}_{2}$ & - & $\mathrm{TBAB}^{\mathrm{e}}$ & 36 & 92 \\
\hline 8 & 0.05 & $\mathrm{NaOAc}$ & $\mathrm{NMP} / \mathrm{H}_{2} \mathrm{O} \quad 2: 1$ & $\mathrm{~N}_{2}$ & - & $\mathrm{TBAB}^{\mathrm{e}}$ & 44 & 84 \\
\hline 9 & 0.05 & $\mathrm{~K}_{2} \mathrm{CO}_{3}$ & $\mathrm{NMP} / \mathrm{H}_{2} \mathrm{O} 2: 1$ & $\mathrm{~N}_{2}$ & - & $\mathrm{TBAB}^{\mathrm{e}}$ & 11 & 91 \\
\hline 10 & 0.05 & $\mathrm{~K}_{2} \mathrm{CO}_{3}$ & $\mathrm{NMP} / \mathrm{H}_{2} \mathrm{O} 2: 1$ & $\mathrm{~N}_{2}$ & $\mathrm{PPh}_{3}{ }^{\mathrm{f}}$ & $\mathrm{TBAB}^{\mathrm{e}}$ & 24 & 96 \\
\hline 11 & 0.05 & $\mathrm{NaOAc}$ & $\mathrm{NMP} / \mathrm{H}_{2} \mathrm{O} 2: 1$ & $\mathrm{~N}_{2}$ & $\mathrm{PPh}_{3}{ }^{\mathrm{f}}$ & $\mathrm{TBAB}^{\mathrm{e}}$ & 17 & 99 \\
\hline 12 & 0.12 & NaOAc & $\mathrm{NMP} / \mathrm{H}_{2} \mathrm{O} 2: 1$ & $\mathbf{N}_{2}$ & - & $\mathbf{T B A B}^{\mathrm{e}}$ & 89 & 87 \\
\hline 13 & 0.12 & NaOAc & $\mathrm{NMP} / \mathrm{H}_{2} \mathrm{O}$ 2:1 & $\mathbf{N}_{2}$ & - & - & 62 & 82 \\
\hline $\begin{array}{l}{ }^{\mathrm{a}} \text { reacti } \\
24 \mathrm{~h} . \\
{ }^{\mathrm{b}} \text { conve } \\
{ }^{\mathrm{c}} \mathrm{I}_{2}: 0.1 \\
{ }^{\mathrm{d}} \mathrm{nd}: \mathrm{nc} \\
{ }^{\mathrm{e}} \mathrm{TBAL} \\
{ }^{\mathrm{C}} \mathrm{PPh}_{3} \text { : }\end{array}$ & $\begin{array}{l}\text { on conditic } \\
\text { sion and s } \\
\text { mol\% } \\
\text { determin } \\
: 60 \mathrm{~mol} \% \\
0 \mathrm{~mol} \%\end{array}$ & $\begin{array}{l}\text { odobenze } \\
\text { ivity were }\end{array}$ & (0.10 mmol), sty & $\begin{array}{l}\text { ene }(0.14 \mathrm{mmo} \\
\text { MS analysis }\end{array}$ & Eco-P & oase $(0$ & mmol), solvent & $(2 \mathrm{~mL}), 140^{\circ} \mathrm{C}$, \\
\hline
\end{tabular}

We started our investigation by using very low catalytic loadings ( $0.05 \mathrm{~mol} \%$ of $\mathrm{Pd})$, without any ligand, as for the beginning of the study of Suzuki-Miyaura coupling, following the conditions described by De Vries et al. [70]. A first run gave $25 \%$ conversion (table 11 , entry 1 ), proving that the $\mathrm{Eco}-\mathrm{Pd}_{3}{ }^{\circledR}$ promotes the reaction. We then attempted to raise the conversion by increasing the catalytic loading of Pd from 0.05 to $0.2 \mathrm{~mol} \%$. Unfortunately, the conversion dramatically dropped to $8 \%$ (table 11 , entry 2 ). This result can be explained by the aggregation of Pd into insoluble Pd black, ineffective in the reaction, as reported by De Vries et al. when using Pd loadings higher than $0.1 \mathrm{~mol} \%$ in the absence of stabilizing ligands. In order to avoid this loss of activity, the addition of catalytic amounts of $\mathrm{I}_{2}$ as a reactivating agent of Pd precipitate was investigated [71]. 
Although we observed a small increase in conversion (35\%, table 11, entry 3 ) and selectivity (91\%), these modified conditions did not significantly improve the conversion, even using higher loadings of $\mathrm{I}_{2}$. Additionally, the utilization of triethylamine as base proved to be totally inefficient in our case (entry 4), whereas it was selected as the best base in the original conditions of De Vries et al. [71]. The use of n-tetrabutylammonium bromide as stabilizing agent of Pd active species was then investigated, as suggested by of Kleist et al. [72] and inspired by works of Jeffery [73]. As expected, conversion increased, reaching $43 \%$ after 24 hours of reaction (table 11, entry 5). Under identical reaction conditions, when using catalytic loadings of Pd lower than 0.05 $\mathrm{mol} \%$, the reaction was still possible, but the conversion was too low and the reaction time too long (exceeding 24 hours) to be of practical interest. Interestingly, when the reaction was performed under air instead of inert $\mathrm{N}_{2}$ atmosphere, almost no reaction occurred (tale 11, entry 6). This observation was consistent with previous reports of formation of oxidized species of Pd in presence of $\mathrm{O}_{2}$, whereas in our case we did not observed any side reaction but only an absence of conversion [74]. The addition of water was also investigated, as Jeffery highlighted its role in solubilizing TBAB and providing an optimal activity [73]. Several NMP/water ratios were tested. The NMP/water ratio of 2:1 was the most efficient one, but did not improve significantly the conversion (table 11, entries 5 and 6-8). In order to compare our results with those of Jeffery, $\mathrm{K}_{2} \mathrm{CO}_{3}$ was tested as base (entry 9), alone and in association with $\mathrm{PPh}_{3}$ as ligand (entry 10). Poor conversions were observed, confirming that our catalytic system was more efficient without ligand. Interestingly, a dramatic conversion increase to $89 \%$ was observed by a simple increase of Pd loading from 0.05 to $0.12 \mathrm{~mol} \%$ (table 11 , entry 12 ). This result was clearly an illustration of the effect of TBAB in aqueous NMP, as the suppression of this reagent led to only $62 \%$ conversion. Moreover, it should be noted that without TBAB, the aggregation of the Pd active species into Pd black was less pronounced in aqueous NMP (table 11, entry 13) than in pure NMP (table 11, entry 2), even when Pd loadings higher than $0.1 \mathrm{~mol} \%$ were used.

Our optimized reaction conditions (NaOAc, $0.12 \mathrm{~mol} \% \mathrm{Pd}$, NMP/water 2:1, TBAB) were then applied to other substrates, confirming the efficiency of the methodology (table 12). Good conversion and selectivity were observed on aryl iodides and bromides. In its present form, the method was not adapted to aryl chlorides, according to their low reactivity in this reaction. Nevertheless, the reaction was possible on other classically less reactive substrates such as 4-iodoanisole (table 12, entry 3) or 3-bromobenzaldehyde (table 12, entry 6). Conversion and selectivity obtained with $\mathrm{Eco}-\mathrm{Pd}_{3}{ }^{\circledR}$ are similar or superior to those obtained with several conventional Pd-based catalysts (table 12, entries 7-9).

Table 12. Heck-Mizoroki cross-coupling of aryl halides and alkenes catalyzed by Eco- $\mathrm{Pd}_{3}{ }^{\circledR}$

Entry ${ }^{\mathrm{a}}$ Aryl halide Alkene


5

6<smiles>O=[N+]([O-])c1ccc(Br)cc1</smiles>

0.12<smiles>O=[N+]([O-])c1ccc(/C=C/c2ccccc2)cc1</smiles>

0.12<smiles>O=Cc1cccc(C=Cc2ccccc2)c1</smiles>

0.10<smiles>C(=C/c1ccccc1)\c1ccccc1</smiles>

2.0<smiles>COC(=O)/C=C/c1ccccc1</smiles>

97<smiles>CC(=O)c1ccc(/C=C/c2ccccc2)cc1</smiles>

74

This work
9<smiles>C=Cc1ccccc1</smiles>

0.10<smiles>C=C(C)C(C)=O</smiles>

\footnotetext{
${ }^{\mathrm{a}}$ reaction conditions: aryl halide $(0.10 \mathrm{mmol})$, alkene $(0.14 \mathrm{mmol}), \mathrm{Eco}-\mathrm{Pd}_{3}(0.12 \mathrm{~mol} \%), \mathrm{NaOAc}(0.13 \mathrm{mmol})$, TBAB (0.06 mmol), NMP/water 2:1 (2 mL), $140{ }^{\circ} \mathrm{C}, 24 \mathrm{~h}$.

${ }^{\mathrm{b}}$ conversion and selectivity were determined by GC-MS analysis

${ }^{c}$ reaction conditions: aryl halide $(4.0 \mathrm{mmol})$, alkene $(5.6 \mathrm{mmol}),\left[\left(\mathrm{PdCl}\left(\eta^{3}-\mathrm{C}_{3} \mathrm{H}_{5}\right)\right)_{2}\right.$ (bisguanidine $\left.)\right](0.10 \mathrm{~mol} \%), \mathrm{NaOAc}$ (4.4 mmol), DMF $(5 \mathrm{~mL}), 165^{\circ} \mathrm{C}, 85 \mathrm{~min}$.

d reaction conditions: aryl halide $(1.0 \mathrm{mmol})$, acrylate $(2.0 \mathrm{mmol}), \mathrm{Pd} / \mathrm{PVA}$ nanofiber $(2.0 \mathrm{~mol} \%), \mathrm{KOAc}(3.0 \mathrm{mmol})$, $\operatorname{DMSO}(5 \mathrm{~mL}), 110^{\circ} \mathrm{C}, 4 \mathrm{~h}$.

${ }^{\mathrm{e}}$ reaction conditions: aryl halide $(10.0 \mathrm{mmol})$, alkene $(15.0 \mathrm{mmol}), \mathrm{Pd} / \mathrm{C}(0.10 \mathrm{~mol} \%), \mathrm{NaOAc}(12.0 \mathrm{mmol}), \mathrm{DMAc}(10$ $\mathrm{mL}), 120^{\circ} \mathrm{C}, 20 \mathrm{~h}$.
}

\subsection{Discussion}

The high efficiency of Eco-Pd ${ }_{3}^{\circledR}$ in Suzuki-Miyaura and Heck-Mizoroki cross-coupling reactions may be explained by the original polymetallic composition of the catalyst, which stems from its vegetal origin. This point was not discussed in previous work on laboratory plant-based catalysts [66], but it appears as a very important factor which has to be considered for several reasons.

It is commonly accepted that, for simple supported Pd catalysts, the best catalyst performance can be achieved mainly by the following two features [78]:

(i) Pd should be highly dispersed on the support surface

(ii) Pd should be present as $\mathrm{Pd}(\mathrm{II})$

In Eco-Pd ${ }_{3}{ }^{\circledR}, \mathrm{Pd}$ dispersion by other physiological cations (as highlighted by ICP-MS analyses, ICP-MS analysis of Eco-Pd ${ }^{\otimes}$, section 3.2., table 3) would avoid Pd aggregation leading to catalyst deactivation by forming inactive Pd black. Moreover, according to the literature, additional cations may play an important role in the catalytic activity of Eco- $\mathrm{Pd}_{3}{ }^{\circledR}$.

Several studies have shown that oxidative addition and transmetallation steps are accelerated by the presence of metal cations. The hypothesis of Amatore et al. is based on the interaction between metallic cations and halide anions bound to the palladium ( 0 ) by ion pairing, thus affording more free and reactive palladium species [79]. Furthermore, Fan et al. have tested the activity of several Lewis acids to assist the polarization of the arylhalogen bond during palladium-catalyzed Suzuki-Miyaura reaction [80]. Significant rate-enhancement in HeckMizoroki reaction has been reported by the additions of catalytic amounts of Lewis acids such as $\mathrm{FeCl}_{3}[81]$. 
The addition of simple inorganic salts such as $\mathrm{NaCl}, \mathrm{KCl}, \mathrm{Na}_{2} \mathrm{SO}_{4}$ and $\mathrm{K}_{2} \mathrm{SO}_{4}$ may also enhance the catalytic activity of palladium (II) species via the formation of soluble ate complexes [82], like $\mathrm{Na}_{2} \mathrm{PdCl}_{4}$, whose presence is suggested in Eco- $\mathrm{Pd}_{3}{ }^{\circledR}$ (see XPS, XRD and EDS analyses section 3.2).

Finally, it was shown that the presence of inorganic salts can considerably accelerate the Suzuki-Miyaura coupling reaction of bromoarenes catalyzed by pre-formed Pd nanoparticles [83]. The interactions between the charged salt surface and the catalyst/reactants may be the main reasons for this effect.

All these effects may contribute to the high catalytic activity we observed in the case of the Eco-Pd ${ }^{\circledR}$ materials in Heck-Mizoroki- and Suzuki-Miyaura cross-coupling reactions.

The significant advantages of Eco-Pd ${ }^{\circledR}$ for Suzuki-Miyaura and Heck-Mizoroki coupling reactions are a straightforward preparation of the catalyst and a very high catalytic activity. We believe that the presence of others non-toxic salt particles enhances the protocol and rate of these reactions. We have provided a simple and green plant-based methodology for cross-coupling reactions. In terms of Green Chemistry, this process is of great interest because of such low Pd loading and waste is largely minimized in the absence of conventional ligand and additives.

\section{Conclusion}

Eco-Pd ${ }^{\circledR}$ catalysts enable innovative recovery of metal charged biomass from plants used in rhizofiltration to decontaminate effluents rich in palladium. L. multiflorum is particularly attractive for phytoremediation of palladium, thanks to its root biomass. Eco-Pd ${ }^{\circledR}$ produced from plants' roots show valuable physicochemical properties, regarding their Lewis acidity, their composition and their physical structure, especially with the presence of dispersed nanosized palladium particles. These properties are assets in Suzuki-Miyaura and HeckMizoroki cross-coupling reactions. Indeed, Eco-Pd ${ }^{\circledR}$, especially Eco- $\mathrm{Pd}_{3}{ }^{\circledR}$ show unprecedented results in both reactions, in terms of selectivity and reactivity. Eco-Pd ${ }^{\circledR}$ ought to be recyclable, and further studies are currently ongoing in our laboratory. An easy recovery of Eco-Pd ${ }^{\mathbb{B}}$ would be another valuable asset in term of Green Chemistry.

\section{Acknowledgements}

We are very grateful to Marine Mazel (Stratoz Company), Clémence Bes (CNRS) and Richard Quentin (CNRS) for their assistance during Plant growth under rhizofiltration. 


\section{References}

[1] Z. Lu, S. Ma, Metal-Catalyzed Enantioselective Allylation in Asymmetric Synthesis, Angew. Chem., Int. Ed., 47 (2008) 258-297.

[2] Selectivity in Palladium-Catalyzed Allylic Substitution, in: U. Kazmaier (Ed.) Transition Metal Catalyzed Enantioselective Allylic Substitution in Organic Synthesis, Springer, Berlin Heidelberg, 2012.

[3] D.S. Surry, S.L. Buchwald, Dialkylbiaryl phosphines in Pd-catalyzed amination: a user's guide, Chemical Science, 2 (2011) 27-50.

[4] J.F. Hartwig, Evolution of a Fourth Generation Catalyst for the Amination and Thioetherification of Aryl Halides, Acc. Chem. Res., 41 (2008) 1534-1544.

[5] A.d. Meijere, F.o. Diederich, Metal-catalyzed cross-coupling reactions, 2nd, completely rev. and enl. ed., WileyVCH, Weinheim, 2004.

[6] R.F. Heck, J.P. Nolley, Palladium-catalyzed vinylic hydrogen substitution reactions with aryl, benzyl, and styryl halides, J. Org. Chem., 37 (1972) 2320-2322.

[7] N. Miyaura, K. Yamada, A. Suzuki, A new stereospecific cross-coupling by the palladium-catalyzed reaction of 1-alkenylboranes with 1-alkenyl or 1-alkynyl halides, Tetrahedron Lett., 20 (1979) 3437-3440.

[8] C.C.C. Johansson Seechurn, M.O. Kitching, T.J. Colacot, V. Snieckus, Palladium-Catalyzed Cross-Coupling: A Historical Contextual Perspective to the 2010 Nobel Prize, Angew. Chem., Int. Ed., 51 (2012) 5062-5085.

[9] G.A. Molander, N. Ellis, Organotrifluoroborates: Protected Boronic Acids That Expand the Versatility of the Suzuki Coupling Reaction, Acc. Chem. Res., 40 (2007) 275-286.

[10] R. Martin, S.L. Buchwald, Palladium-Catalyzed Suzuki-Miyaura Cross-Coupling Reactions Employing Dialkylbiaryl Phosphine Ligands, Acc. Chem. Res., 41 (2008) 1461-1473.

[11] M. Oestreich, The Mizoroki-Heck reaction, Wiley, Hoboken, N.J., 2009.

[12] I.P. Beletskaya, A.V. Cheprakov, The Heck Reaction as a Sharpening Stone of Palladium Catalysis, Chem. Rev., 100 (2000) 3009-3066.

[13] C. Deraedt, D. Astruc, "Homeopathic" Palladium Nanoparticle Catalysis of Cross Carbon-Carbon Coupling Reactions, Acc. Chem. Res., 47 (2014) 494-503.

[14] Palladium-Catalyzed Cross-Coupling Reactions, Wiley-VCH Verlag GmbH \& Co. KGaA, Weinheim, 2013.

[15] G. Losfeld, V. Escande, P.V. de La Blache, L. L'Huillier, C. Grison, Design and performance of supported Lewis acid catalysts derived from metal contaminated biomass for Friedel-Crafts alkylation and acylation, Catal. Today, 189 (2012) 111-116.

[16] G. Losfeld, P.V. de la Blache, V. Escande, C. Grison, Zinc hyperaccumulating plants as renewable resources for the chlorination process of alcohols, Green Chem. Lett. Rev., 5 (2012) 451-456.

[17] C. Grison, J. Escarré, Use of metal-accumulating plants for the preparation of catalysts that can be used in chemical reactions WO 2011064462 A1 20110603, 2011.

[18] C. Grison, J. Escarré, Use of metal accumulating plants for the preparation of catalysts that can be used in chemical reactions WO 2011064487 A1 20110603, 2011.

[19] G. Losfeld, L. L’Huillier, B. Fogliani, T. Jaffré, C. Grison, Mining in New Caledonia: environmental stakes and restoration opportunities, Environ. Sci. Pollut. Res., (2014) in press, 10.1007/s11356-014-3358-x.

[20] G. Losfeld, L. L'Huillier, B. Fogliani, S. Coy, C. Grison, T. Jaffré, Leaf-age and soil-plant relationships: key factors for reporting trace-elements hyperaccumulation by plants and design applications, Environ. Sci. Pollut. Res., (2014) in press, 10.1007/s11356-014-3445-z.

[21] C.M. Grison, M. Mazel, A. Sellini, V. Escande, J. Biton, C. Grison, The leguminous species Anthyllis vulneraria as a Zn-hyperaccumulator and eco-Zn catalyst resources, Environ. Sci. Pollut. Res., (2014) in press, 10.1007/s11356014-3605-1.

[22] G. Losfeld, V. Escande, T. Jaffre, L. L'Huillier, C. Grison, The chemical exploitation of nickel phytoextraction: An environmental, ecologic and economic opportunity for New Caledonia, Chemosphere, 89 (2012) 907-910.

[23] V. Escande, L. Garoux, C. Grison, Y. Thillier, F. Debart, J.J. Vasseur, C. Boulanger, C. Grison, Ecological catalysis and phytoextraction: Symbiosis for future, Appl. Catal., B, 146 (2014) 279-288.

[24] V. Escande, T.K. Olszewski, C. Grison, Preparation of ecological catalysts derived from Zn hyperaccumulating plants and their catalytic activity in Diels-Alder reaction, C. R. Chim., 17 (2014) 731-737.

[25] Y. Thillier, G. Losfeld, V. Escande, C. Dupouy, J.J. Vasseur, F. Debart, C. Grison, Metallophyte wastes and polymetallic catalysis: a promising combination in green chemistry. The illustrative synthesis of 5 '-capped RNA, RSC Adv., 3 (2013) 5204-5212. 
[26] V. Escande, T.K. Olszewski, E. Petit, C. Grison Biosourced Polymetallic Catalysts: An Efficient Means To Synthesize Underexploited Platform Molecules from Carbohydrates, ChemSusChem, 7 (2014) 1915-1923.

[27] C. Grison, V. Escande, E. Petit, L. Garoux, C. Boulanger, C. Grison, Psychotria douarrei and Geissois pruinosa, novel resources for the plant-based catalytic chemistry, RSC Adv., 3 (2013) 22340-22345.

[28] V. Escande, T. Olszewski, C. Grison, From biodiversity to catalytic diversity: how to control the reaction mechanism by the nature of metallophytes, Environ. Sci. Pollut. Res., (2014) in press, 10.1007/s11356-014-3483-6.

[29] V. Escande, A. Velati, C. Grison, Ecocatalysis for 2H-chromenes synthesis: an integrated approach for phytomanagement of polluted ecosystems, Environ. Sci. Pollut. Res., (2014) in press, 10.1007/s11356-014-3433-3.

[30] C.M. Grison, A. Velati, V. Escande, C. Grison, Metallophytes for organic synthesis: towards new bio-based selective protection/deprotection procedures, Environ. Sci. Pollut. Res., (2014) in press, 10.1007/s11356-014-3526-z. [31] V. Escande, B.-L. Renard, C. Grison, Lewis acid catalysis and Green oxidations: sequential tandem oxidation processes induced by Mn-hyperaccumulating plants, Environ. Sci. Pollut. Res., (2014) in press, 10.1007/s11356-0143631-z.

[32] R. Bali, R. Siegele, A.T. Harris, Biogenic Pt uptake and nanoparticle formation in Medicago sativa and Brassica juncea, J. Nanopart. Res., 12 (2010) 3087-3095.

[33] J. Kwiatkowska-Malina, A. Maciejewska, Soil Science Annual, 64 (2013) 19-23.

[34] B.A. Lesniewska, J. Messerschmidt, N. Jakubowski, A. Hulanicki, Bioaccumulation of platinum group elements and characterization of their species in Lolium multiflorum by size-exclusion chromatography coupled with ICP-MS, Sci. Total Environ., 322 (2004) 95-108.

[35] R.G. Pearson, Hard and Soft Acids and Bases Hsab .1. Fundamental Principles, J. Chem. Educ., 45 (1968) 581587.

[36] R.G. Pearson, The HSAB principle - More quantitative aspects, Inorg. Chim. Acta, 240 (1995) 93-98.

[37] A. Corma, H. Garcia, A. Primo, A. Domenech, A test reaction to assess the presence of Bronsted and the softness/hardness of Lewis acid sites in palladium supported catalysts, New J. Chem., 28 (2004) 361-365.

[38] M.I. Zaki, M.A. Hasan, F.A. Al-Sagheer, L. Pasupulety, In situ FTIR spectra of pyridine adsorbed on SiO2$\mathrm{Al} 2 \mathrm{O} 3, \mathrm{TiO} 2, \mathrm{ZrO} 2$ and $\mathrm{CeO} 2$ : general considerations for the identification of acid sites on surfaces of finely divided metal oxides, Colloid. Surface A, 190 (2001) 261-274.

[39] E.P. Parry, An infrared study of pyridine adsorbed on acidic solids. Characterization of surface acidity, J. Catal., 2 (1963) 371-379.

[40] M.V. Baldovi, A. Corma, V. Fornes, H. Garcia, A. Martinez, J. Primo, Soft and Hard Acidity in Ion-Exchanged Y-Zeolites - Rearrangement of 2-Bromopropiophenone Ethylene Acetal to 2-Hydroxyethyl 2-Phenylpropanoate, J. Chem. Soc., Chem. Commun., (1992) 949-951.

[41] L. Alaerts, E. Seguin, H. Poelman, F. Thibault-Starzyk, P.A. Jacobs, D.E. De Vos, Probing the Lewis acidity and catalytic activity of the metal-organic framework [Cu-3(btc)(2)] (BTC = benzene-1,3,5-tricarboxylate), Chem. Eur. J., 12 (2006) 7353-7363.

[42] K. Noack, H. Zbinden, R. Schlögl, Identification of the state of palladium in various hydrogenation catalysts by XPS, Catal. Lett., 4 (1990) 145-155.

[43] M. Brun, A. Berthet, J.C. Bertolini, XPS, AES and Auger parameter of Pd and PdO, J. Electron. Spectrosc. Relat. Phenom., 104 (1999) 55-60.

[44] T. Pillo, R. Zimmermann, P. Steiner, S. Hufner, The electronic structure of PdO found by photoemission (UPS and XPS) and inverse photoemission (BIS), Journal of Physics-Condensed Matter, 9 (1997) 3987-3999.

[45] J.C. Bertolini, P. Delichere, B.C. Khanra, J. Massardier, C. Noupa, B. Tardy, Electronic properties of supported Pd aggregates in relation with their reactivity for 1,3-butadiene hydrogenation, Catal. Lett., 6 (1990) 215-223.

[46] H. Seyama, M. Soma, X-ray photoelectron spectroscopic study of montmorillonite containing exchangeable divalent cations, Journal of the Chemical Society, Faraday Transactions 1: Physical Chemistry in Condensed Phases, 80 (1984) 237-248.

[47] M. Shiozawa, H. Takahashi, N. Iwasaki, T. Wada, M. Uo, Effect of immersion time of restorative glass ionomer cements and immersion duration in calcium chloride solution on surface hardness, Dent. Mater., (2014) in press DOI: 10.1016/j.dental.2014.1008.1366.

[48] J. Tsuji, C. Nájera, D.A. Alonso, Potassium Tetrachloropalladate(II), Encyclopedia of Reagents for Organic Synthesis, John Wiley \& Sons, Ltd2001.

[49] G. Kumar, J.R. Blackburn, R.G. Albridge, W.E. Moddeman, M.M. Jones, Photoelectron spectroscopy of coordination compounds. II. Palladium complexes, Inorg. Chem., 11 (1972) 296-300.

[50] N. Miyaura, A. Suzuki, Palladium-Catalyzed Cross-Coupling Reactions of Organoboron Compounds, Chem. Rev., 95 (1995) 2457-2483.

[51] A. Suzuki, Cross-Coupling Reactions Of Organoboranes: An Easy Way To Construct C $\square \mathrm{C}$ Bonds (Nobel Lecture), Angew. Chem., Int. Ed., 50 (2011) 6722-6737. 
[52] N. Miyaura, T. Yanagi, A. Suzuki, The Palladium-Catalyzed Cross-Coupling Reaction of Phenylboronic Acid with Haloarenes in the Presence of Bases, Synth. Commun., 11 (1981) 513-519.

[53] T. Mizoroki, K. Mori, A. Ozaki, Arylation of Olefin with Aryl Iodide Catalyzed by Palladium, Bull. Chem. Soc. Jpn., 44 (1971) 581-581.

[54] N.T.S. Phan, M. Van Der Sluys, C.W. Jones, On the Nature of the Active Species in Palladium Catalyzed Mizoroki-Heck and Suzuki-Miyaura Couplings - Homogeneous or Heterogeneous Catalysis, A Critical Review, Adv. Synth. Catal., 348 (2006) 609-679.

[55] J. Hassan, M. Sévignon, C. Gozzi, E. Schulz, M. Lemaire, Aryl-Aryl Bond Formation One Century after the Discovery of the Ullmann Reaction, Chem. Rev., 102 (2002) 1359-1470.

[56] Yin, J. Liebscher, Carbon-Carbon Coupling Reactions Catalyzed by Heterogeneous Palladium Catalysts, Chem. Rev., 107 (2006) 133-173.

[57] A.O. King, I. Shinkai, Palladium on Carbon, Encyclopedia of Reagents for Organic Synthesis, John Wiley \& Sons, Ltd2001.

[58] A. Roucoux, J. Schulz, H. Patin, Reduced Transition Metal Colloids: A Novel Family of Reusable Catalysts?, Chem. Rev., 102 (2002) 3757-3778.

[59] D. Astruc, Palladium Nanoparticles as Efficient Green Homogeneous and Heterogeneous Carbon-Carbon Coupling Precatalysts: A Unifying View, Inorg. Chem., 46 (2007) 1884-1894.

[60] A. Fihri, M. Bouhrara, B. Nekoueishahraki, J.M. Basset, V. Polshettiwar, Nanocatalysts for Suzuki crosscoupling reactions, Chem. Soc. Rev., 40 (2011) 5181-5203.

[61] A. Alimardanov, L. Schmieder-van de Vondervoort, A.H.M. de Vries, J.G. de Vries, Use of "Homeopathic" Ligand-Free Palladium as Catalyst for Aryl-Aryl Coupling Reactions, Adv. Synth. Catal., 346 (2004) 1812-1817.

[62] R.K. Arvela, N.E. Leadbeater, M.S. Sangi, V.A. Williams, P. Granados, R.D. Singer, A reassessment of the transition-metal free Suzuki-type coupling methodology, J. Org. Chem., 70 (2005) 161-168.

[63] C. Liu, Q. Ni, P. Hu, J. Qiu, Oxygen-promoted PdCl2-catalyzed ligand-free Suzuki reaction in aqueous media, Org. Biomol. Chem., 9 (2011) 1054-1060.

[64] C. Liu, Q.J. Ni, F.Y. Bao, J.S. Qiu, A simple and efficient protocol for a palladium-catalyzed ligand-free Suzuki reaction at room temperature in aqueous DMF, Green Chem., 13 (2011) 1260-1266.

[65] M. Amini, M. Bagherzadeh, Z. Moradi-Shoeili, D.M. Boghaei, $\mathrm{Pd}(\mathrm{OAc}) 2$ without added ligand as an active catalyst for Mizoroki-Heck reaction in aqueous media, RSC Adv., 2 (2012) 12091-12095.

[66] H.L. Parker, E.L. Rylott, A.J. Hunt, J.R. Dodson, A.F. Taylor, N.C. Bruce, J.H. Clark, Supported Palladium Nanoparticles Synthesized by Living Plants as a Catalyst for Suzuki-Miyaura Reactions, PLoS One, 9 (2014).

[67] Y.-X. Xie, J. Wang, J.-H. Li, Y. Liang, Reusable and Ligand-Free Palladium-Catalyzed Suzuki-Miyaura CrossCouplings of Aryl Halides with Arylboronic Acids in Tetra-n-butylammonium Bromide, Chin. J. Chem . 26 (2008) 2261-2266.

[68] C.D. Pan, M.C. Liu, L. Zhang, H.Y. Wu, J.C. Ding, J. Cheng, Palladium catalyzed ligand-free Suzuki crosscoupling reaction, Catal. Commun., 9 (2008) 508-510.

[69] R.G. Heidenreich, K. Kohler, J.G.E. Krauter, J. Pietsch, Pd/C as a highly active catalyst for Heck, Suzuki and Sonogashira reactions, Synlett, (2002) 1118-1122.

[70] A.H.M. de Vries, J.M.C.A. Mulders, J.H.M. Mommers, H.J.W. Henderickx, J.G. de Vries, Homeopathic Ligand-Free Palladium as a Catalyst in the Heck Reaction. A Comparison with a Palladacycle, Org. Lett., 5 (2003) 3285-3288.

[71] A.H.M. de Vries, F.J. Parlevliet, L. Schmieder-van de Vondervoort, J.H.M. Mommers, H.J.W. Henderickx, M.A.M. Walet, J.G. de Vries, A practical recycle of a ligand-free palladium catalyst for Heck reactions, Adv. Synth. Catal., 344 (2002) 996-1002.

[72] W. Kleist, S.S. Prockl, K. Kohler, Heck reactions of aryl chlorides catalyzed by ligand free palladium salts, Catal. Lett., 125 (2008) 197-200.

[73] T. Jeffery, Heck-Type Reactions in Water, Tetrahedron Lett., 35 (1994) 3051-3054.

[74] T. Hosokawa, T. Kamiike, S.-I. Murahashi, M. Shimada, T. Sugafuji, The Heck reaction in the presence of molecular oxygen, Tetrahedron Lett., 43 (2002) 9323-9325.

[75] A. Maronna, O. Hübner, M. Enders, E. Kaifer, H.-J. Himmel, Bisguanidines with Biphenyl, Binaphthyl, and Bipyridyl Cores: Proton-Sponge Properties and Coordination Chemistry, Chemistry - A European Journal, 19 (2013) 8958-8977.

[76] L. Shao, W. Ji, P. Dong, M. Zeng, C. Qi, X.-M. Zhang, Coupling reactions of aromatic halides with palladium catalyst immobilized on poly(vinyl alcohol) nanofiber mats, Appl. Catal., A, 413-414 (2012) 267-272.

[77] R.G. Heidenreich, J.G.E. Krauter, J. Pietsch, K. Köhler, Control of Pd leaching in Heck reactions of bromoarenes catalyzed by Pd supported on activated carbon, J. Mol. Catal. A: Chem., 182-183 (2002) 499-509. 
[78] K. Köhler, K. Wussow, A.S. Wirth, Palladium-Catalyzed Cross-Coupling Reactions - A General Introduction, Palladium-Catalyzed Coupling Reactions, Wiley-VCH Verlag GmbH \& Co. KGaA2013, pp. 1-30.

[79] C. Amatore, A. Jutand, Anionic $\operatorname{Pd}(0)$ and $\operatorname{Pd}($ II) Intermediates in Palladium-Catalyzed Heck and CrossCoupling Reactions, Acc. Chem. Res., 33 (2000) 314-321.

[80] G. Fan, H. Zhang, S. Cheng, Z. Ren, Z. Hu, Z. Wang, Lewis Acid-Promoted Suzuki Reaction using Palladium Chloride Anchored on a Polymer as a Catalyst, Aust. J. Chem., 61 (2008) 610-614.

[81] A. Sud, R.M. Deshpande, R.V. Chaudhari, Rate enhancement in palladium catalyzed Heck reactions by Lewis acid promoters, Catal. Commun., 8 (2007) 183-186.

[82] M. Mondal, U. Bora, An efficient protocol for palladium-catalyzed ligand-free Suzuki-Miyaura coupling in water, Green Chem., 14 (2012) 1873-1876.

[83] B. Zhang, J. Song, H. Liu, J. Shi, J. Ma, H. Fan, W. Wang, P. Zhang, B. Han, Acceleration of Suzuki coupling reactions by abundant and non-toxic salt particles, Green Chem., 16 (2014) 1198-1201. 